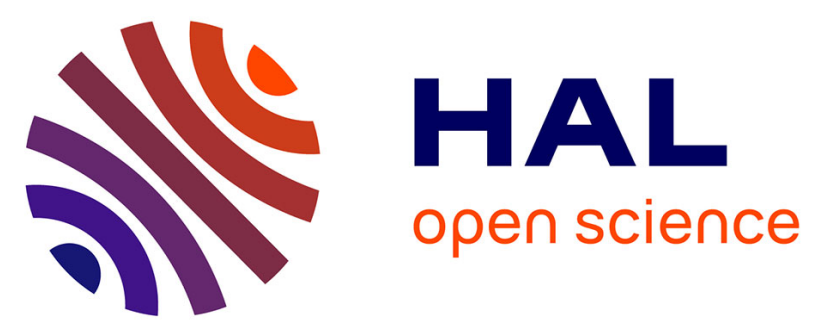

\title{
Where can the Arctic oscillation be reconstructed? Towards a reconstruction of climate modes based on stable teleconnections
}

G. Lohmann, N. Rimbu, M. Dima

\section{- To cite this version:}

G. Lohmann, N. Rimbu, M. Dima. Where can the Arctic oscillation be reconstructed? Towards a reconstruction of climate modes based on stable teleconnections. Climate of the Past Discussions, 2005, 1 (1), pp.17-56. hal-00298110

\section{HAL Id: hal-00298110 \\ https://hal.science/hal-00298110}

Submitted on 25 Jul 2005

HAL is a multi-disciplinary open access archive for the deposit and dissemination of scientific research documents, whether they are published or not. The documents may come from teaching and research institutions in France or abroad, or from public or private research centers.
L'archive ouverte pluridisciplinaire HAL, est destinée au dépôt et à la diffusion de documents scientifiques de niveau recherche, publiés ou non, émanant des établissements d'enseignement et de recherche français ou étrangers, des laboratoires publics ou privés. 
Climate of the Past Discussions, 1, 17-56, 2005

www.climate-of-the-past.net/cpd/1/17/

SRef-ID: $1814-9359 / c p d / 2005-1-17$

European Geosciences Union

Climate

$1,17-56,2005$

\section{Where can the Arctic oscillation be} reconstructed?

\section{Towards a reconstruction of climate modes based on stable teleconnections}

G. Lohmann, N. Rimbu, and M. Dima

Alfred Wegener Institute for Polar and Marine Research, Bremerhaven, Germany

Received: 15 June 2005 - Accepted: 14 July 2005 - Published: 25 July 2005

Correspondence to: G. Lohmann (Lohmann@ awi-bremerhaven.de)

(C) 2005 Author(s). This work is licensed under a Creative Commons License.

Title Page

Abstract

Introduction

Conclusions

References

Tables

Figures

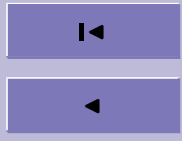

I

Back

Close
Full Screen / Esc

Print Version

Interactive Discussion 


\section{Abstract}

Proxy data can bring observed climate variability of the last 100 years into a long-term context. We identify regions of the Northern Hemisphere where the teleconnection patterns of the Arctic Oscillation are stationary. Our method provides a systematic way 5 to examine optimal sites for the reconstruction of climate modes based on paleoclimatic archives that sensitively record temperature and precipitation variations. We identify the regions for boreal winter and spring that can be used to reconstruct the Arctic Oscillation index in the pre-instrumental period. Finally, this technique is applied to high resolution coral, tree ring, ice core and mollusk shell data to understand proxyclimate teleconnections and their use for climate reconstructions.

\section{Introduction}

Winter atmospheric circulation, air surface temperature and surface precipitation over the Northern Hemisphere are strongly influenced by the Arctic Oscillation (AO) phenomenon (Thompson and Wallace, 1998; Thompson et al., 2000). The AO is the domi-

nant mode of the atmospheric circulation variability in the Northern Hemisphere and it is characterized by a meridional dipole in atmospheric sea level pressure (SLP) between polar regions and mid-latitudes (Thompson and Wallace, 1998). The climate impacts are seen over the North Pacific, the North Atlantic, and over the Northern Hemisphere continents, particularly as milder winters and lengthening of the growing season in Europe and northern Asia. The AO has been attributed to stratosphere-troposphere coupling (Kodera, 1995; Perlwitz and Graf, 1995; Baldwin and Dunkerton, 1999) and includes the North Atlantic Oscillation (NAO) phenomenon (Hurrel, 1995; GlowienkaHense, 1990), which may be considered a different view of the same phenomenon (Thompson et al., 2000). The SLP anticorrelation between the Azores high and Iceland low has been used as a circulation index to characterize the atmospheric circulation in the North Atlantic realm (Defant, 1924; Kutzbach, 1970; Glowienka, 1985). The AO
$1,17-56,2005$

Optimal sites for AO reconstruction

G. Lohmann et al.

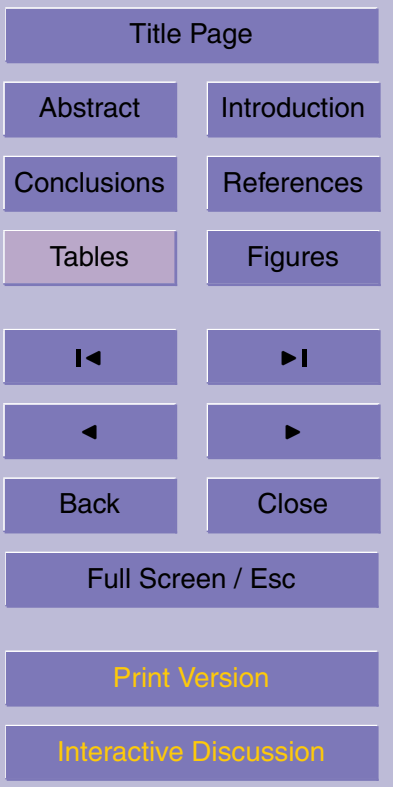


SLP pattern in its positive phase can also be seen as a superposition of the negative phase of the Pacific-North American pattern (Wallace and Gutzler, 1981) and the positive phase of the NAO.

A remarkable feature of the AO/NAO is its trend toward a more positive phase over 5 the past 30 years, with a magnitude that seems to be unprecedented in the observational period (Hurrel, 1995). In order to put the instrumental record into a long term context, proxy data from different paleoclimatic archives have been used to record aspects of AO/NAO variability, as e.g., ice core records (White et al., 1997; Appenzeller et al., 1998; Vinther et al., 2003), tree ring data (Cook et al., 2002), coral data (Felis et 10 al., 2000), mollusk shells (Schöne et al., 2003), and early instrumental and historical data (Jones et al., 1997; Luterbacher et al., 1999).

In most of climate variability mode reconstructions, stationarity in the statistical relationships is assumed in order to construct a transfer function over a part of the instrumental period (calibration) and validate it against another (usually shorter) part of this record (verification) (e.g., Mann et al., 1998, 1999). For a reliable reconstruction of past changes from proxy data it is essential that reconstructions based on these indirect climate indicators be calibrated and independently validated against instrumental records during common intervals of overlap. With this approach the strength of the climate signal in the proxy is assessed by time series regression against instrumental climate data. Another way of elaborating the importance of predictors in the reconstructions is using backward elimination technique as recently be applied by Pauling et al. (2003) for surface air temperature for the North Atlantic European area. By construction, these regression methods strongly depend on the calibration and validation period. In order to give an example, the correlation between NAO and Northern Hemisphere SLP during the last fifty years is weak in the Pacific sector (Deser, 2000). However, significant correlations between the NAO and Pacific climate variability during the 1930s to 1960s have been identified (Walter and Graf, 2002; Knippertz et al., 2003). Variable teleconnections have also been detected in coupled ocean-atmosphere model simulations (Raible et al., 2001; Zorita and Gonzalez-Rouco, 2002). The observed non-
$1,17-56,2005$

\section{Optimal sites for AO} reconstruction

G. Lohmann et al.

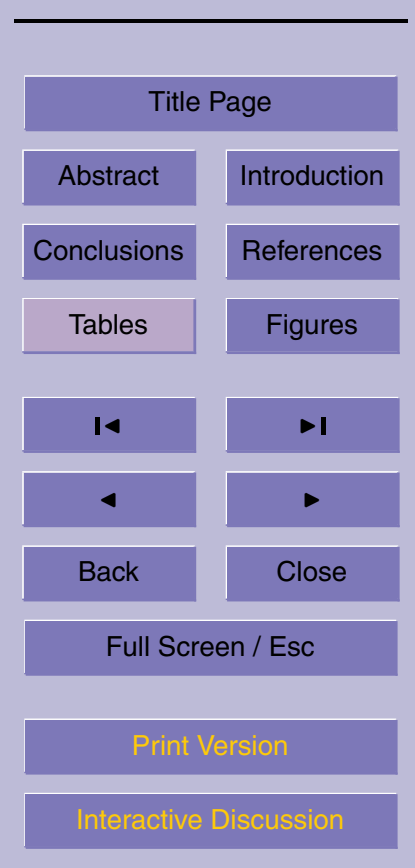


stationarities in the climate system could lead to high correlation and anti-correlation for different periods, e.g. before and after the 1970's climate shift (Rimbu et al., 2003). Similar non-stationarity is reported for Greenland ice cores (Appenzeller et al., 1998; Fischer, 2001) in connection with Northern Hemisphere circulation changes and corals 5 in connection with El Niño-Southern Oscillation (ENSO) (Rimbu et al., 2003; Hendy et al., 2003). Therefore, a systematic way is required to understand these shifts in relation with climate teleconnections.

One goal of this paper is to identify optimal sites for $A O$ reconstructions based on stable teleconnections during the instrumental period. We show that proxy data that are sensitive to temperature and precipitation variations at these locations can be used to reconstruct a large part of $A O$ variability. A second problem arises from seasonality since most of the proxy data have no seasonal resolution. While tree ring information (e.g., Cook et al., 2002) is biased towards the growing season (spring and summer), marine sediment cores (e.g., Conte et al., 1992) are sensitive to the blooming period, the $A O$ phenomenon has its origin in winter. We will address the question of where a winter phenomenon like the $\mathrm{AO}$ can be reconstructed based on climate variations during the spring season. Finally, different types of proxy data will be analyzed in respect to their stable teleconnections.

The paper is organized as follows. Data and methods are presented in Sect. 2. 20 The results of running correlation analysis between the $\mathrm{AO}$ index and temperature and precipitation fields are presented in Sect. 3. Stability maps for several proxy data are presented. The implication of our results on the reconstruction of the Arctic Oscillation index from proxy data is elaborated. In Sect. 4, the results are dicussed and a conclusion follows in Sect. 5.

\section{Data and methods}

The AO index used in this study is derived from the long-term historical sea level (SLP) record constructed by Trenberth and Paolino (1980). The AO index is defined as the

Optimal sites for $\mathrm{AO}$ reconstruction

G. Lohmann et al.

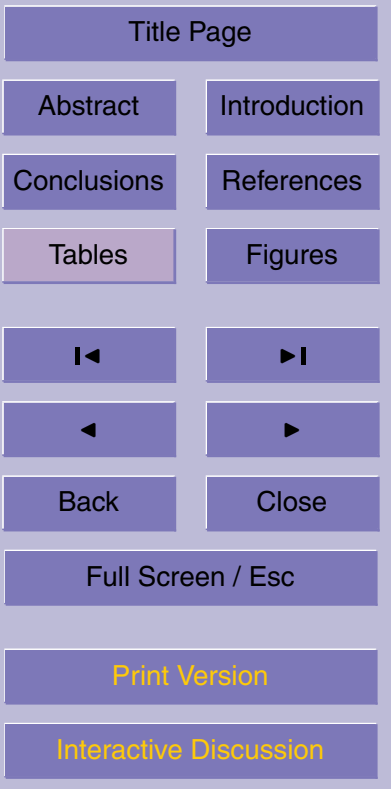


first empirical orthogonal function (EOF) of SLP during January/February. For the period 1900 to 1998 , this explains $21 \%$ of the variance (Fig. 1). For sea surface temperature (SST), we use the dataset of Kaplan et al. (1998), which is now based on observations covering the period 1856-2000 and has a horizontal resolution of $5^{\circ}$.

$5 \quad$ The surface air temperatures over land (ST) used in this study are extracted from the global temperature dataset constructed at the Climate Research Unit, UK (Jones, 1994) with a horizontal resolution of $5^{\circ}$. Other gridded SST data (Rayner et al., 2003; Smith and Reynolds, 2004) and surface air temperature (Jones and Moberg, 2003; Hansen et al., 2001) sets have been applied to our analysis, but the results were un- changed (not shown). Since the observational data is relatively sparse until 1900, only data from 1900 and after is used. Precipitation (PP) data is extracted from the historical global monthly terrestrial precipitation dataset of Hulme and New (1997) which extends from 1900 to 1998 and has a $2.5^{\circ}$ latitude by $3.75^{\circ}$ longitude resolution. For all datasets, we have chosen a common period (1900-1998) of the newest versions for boreal win15 ter (January/February) and spring (March/April). Very similar results are obtained for another definition of the winter and spring seasons, e.g. December/Fanuary/February and March/April/May, respectively.

Furthermore, we used the reconstruction of Pacific Basin SST field $\left(60^{\circ} \mathrm{S}-65^{\circ} \mathrm{N}\right.$, $110^{\circ} \mathrm{E}-65^{\circ} \mathrm{W}$ ) based on thirteen annually averaged coral-derived oxygen isotope time series, using methods described in Evans et al. (2000, 2002). The reconstructed SST fields with a horizontal resolution of $5^{\circ}$ are provided along with the analysis based on the instrumental data as bases for intercomparison of reconstruction methodologies and proxy types. For our analysis, several proxy data sets have been applied which are described in Sect. 3.4.

25 In order to evaluate the stability of climate teleconnections, running correlations between the $\mathrm{AO}$ and the instrumental data are calculated for moving windows (e.g., Gershunov et al., 2000). We have chosen 31 years for the length of the window in order to study whether the strength of the correlation has changed on decadal time scales. The results are not qualitatively changed by reasonable variations of the window length,
$1,17-56,2005$

Optimal sites for $\mathrm{AO}$ reconstruction

G. Lohmann et al.

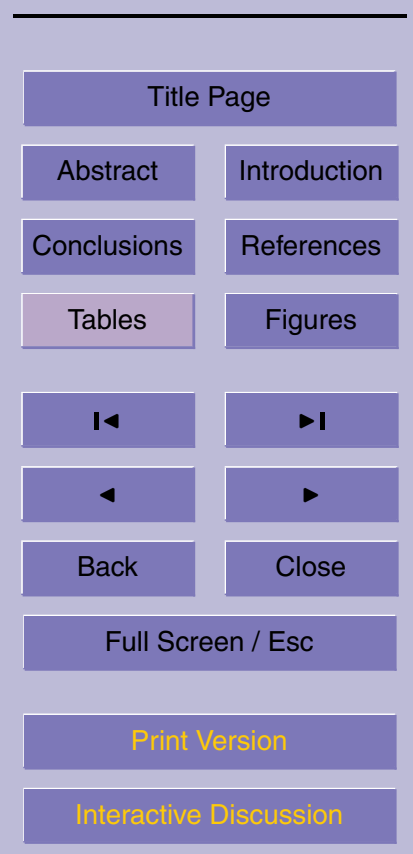


e.g., by choosing 25 years instead of 31 (not shown). For each grid point, the correlation coefficient between the AO index and the time series of SST, ST and PP are calculated. For each calculation of correlations, the data was linearly detrended and normalized by the local standard deviation. Regions are identified where the AO tele5 connections are not strongly influenced by decadal and interdecadal climatic variability.

\section{Stability of the AO teleconnections}

\subsection{Sea surface temperature}

The correlation between the AO index (Fig. 1b) and SST for the period 1900-1998 shows that the AO is related to a coherent large scale Northern Hemisphere SST pattern (Fig. 2a). High values of the AO index are associated with positive SST anomalies over the central and western part of the North Pacific, the western subtropical North Atlantic and the western coast of Europe, while negative anomalies dominate the entire tropical region, the west coast of North America and southwestern Greenland. Approximatly, regions are significant above the 95\% (90\%)-confidence level when the correlation exceeds $\pm 0.2(0.15)$.

Figure $2 \mathrm{~b}$ shows the "islands of stability", which are defined as regions where the running correlations in a 31-year window do not change sign (denoted with "0"). In order to illustrate our method, the running correlation is shown for four grid points located in the Atlantic realm (Fig. 3). After the running correlation, an 11-year running mean has been applied to the running correlation to obtain the thick lines in Fig. 3 . In the North Sea (black line, $62.5^{\circ} \mathrm{N}, 12.5^{\circ} \mathrm{E}$ ), the running correlation of $\mathrm{AO}$ with the local SST exceeds 0.4 and thus does not cross the zero line for all time windows (denoted with "0" in Fig. 2b). The running correlation for the site close to Florida (red line, $22.5^{\circ} \mathrm{N}, 77.5^{\circ} \mathrm{W}$ ) remains also positive, but is below the $90 \%$-confidence level for the 31-year windows centered around 1920 and around 1970. The subtropical Atlantic site (blue line, $32.5^{\circ} \mathrm{N}, 7.5^{\circ} \mathrm{W}$ ) changes its sign of correlation twice (Fig. 3) and
$1,17-56,2005$

\section{Optimal sites for AO} reconstruction

G. Lohmann et al.

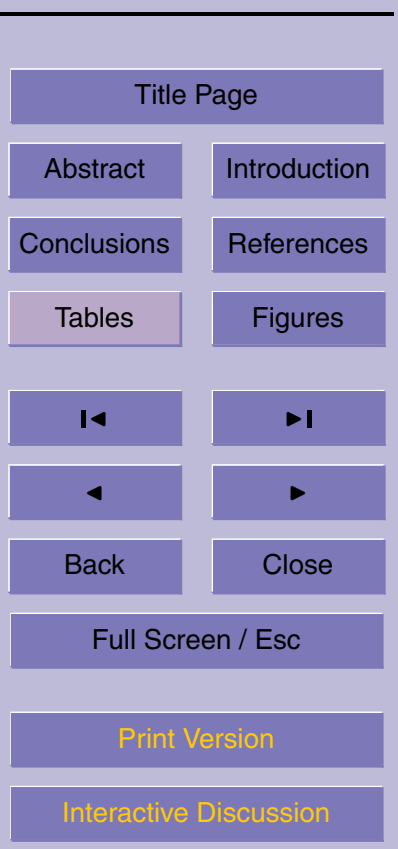


is denoted with "2" in Fig. 2b. Finally, the northern Red Sea site (mangenta, $27.5^{\circ} \mathrm{N}$, $32.5^{\circ} \mathrm{E}$ ) stays above the $90 \%$-confidence level and thus is one of the preferred locations for $\mathrm{AO}$ reconstructions.

We consider a teleconnection to be stable if there is no change in the sign of the 5 correlation coefficient between the local field anomaly and $\mathrm{AO}$ index time series for all windows (blue and mangenta regions in Fig. 2b). Furthermore, if this is significant at at least the $90 \%$ confidence level for all windows in the 1900-1998 time period, we consider the sites as optimal sampling points for AO reconstructions from SST data (blue regions in Fig. $2 b$ ).

10 These purple and blue regions where the correlation in the 31-year windows does not change the sign (Fig. $2 \mathrm{~b}$ ) coincide with the regions where the mean correlation between AO and SST (Fig. 2a) is statistically significant. In the Pacific, three stable regions can be identified: the central Pacific, the western coast of North America and the central to eastern tropical Pacific (Fig. 2b). In the North Atlantic, the AO teleconnection is stable 15 in the center of the typical AO/NAO tri-polar SST structure. We also identify stable regions along the west coast of Europe as well as in the eastern Mediterranean and in the northern Red Sea (Fig. 2b).

Furthermore, we analyze the connection between the winter $A O$ index (Fig. 1b) and spring (March/April) SSTs, since many proxies are sensitive to the spring season. We

find large stable regions in the North Atlantic (Fig. 4). In the Pacific, these regions are less pronounced for spring than for winter (compare Figs. 2 and 4). For the Atlantic, the AO-SST correlation increases for boreal spring relative to winter due to a lagged SST response to atmospheric circulation on interannual time scales.

\subsection{Surface air temperature over land}

25 The surface air temperature correlation map for the period 1900-1998 (Fig. 5a) shows centers of significant correlation consistent with the corresponding SST map. Over land, two main stable regions are identified: a large part of China and a large part of northern Europe (Fig. 5b). In these centers, the correlation is significant above the
$1,17-56,2005$

\section{Optimal sites for AO} reconstruction

G. Lohmann et al.

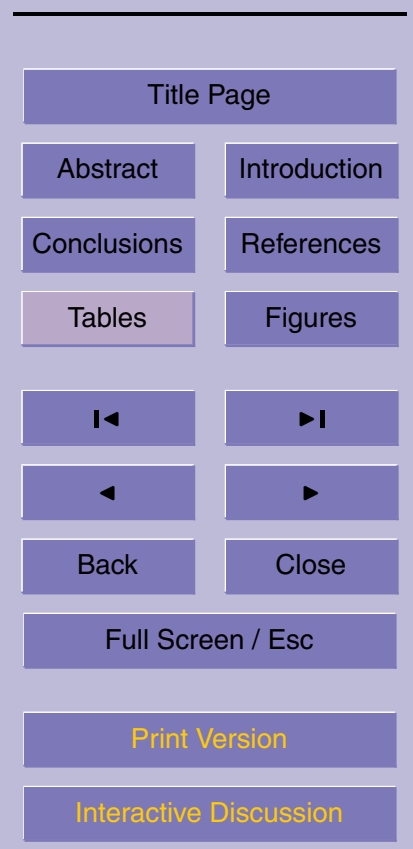


95\% confidence level and the correlation in the 31-year windows does not change sign during the 1900-1998 period. Our correlation map also indicates small such regions over North America, over West-Greenland, and some points in the Middle East. Empty boxes in Fig. $5 \mathrm{~b}$ represent areas with insufficient data (less than $30 \%$ of data for the 5 period 1900-1998). For the boreal spring (Fig. 6), we detect a large region around $40^{\circ} \mathrm{E}$ and $60^{\circ} \mathrm{N}$ that has a stable correlation with the $\mathrm{AO}$ index. Other regions are found over North America and western Asia (Fig. 6).

Stable regions provide possible locations to document $A O$ variations during the preinstrumental period. Figure 7 shows the principal idea behind an AO reconstruction 10 using four different boreal winter sites where the running correlation does not change sign. From the four temperature time series, we evaluate the first EOF and associated principal component (PC1). PC1 is then correlated to the AO index in 31-year windows (solid black line in Fig. 7). This curve indicates that PC1 comprises the AO-climate link of the four sites providing much more information than the individual time series.

15 3.3. Precipitation

The correlation between the AO index and precipitation anomalies for the period 19001998 during boreal winter shows a large area over central Europe of significant negative correlation, bounded south and north by regions dominated by positive correlations (Fig. 8a). The correlation pattern is similar to the second mode of decadal precipita20 tion anomalies over Europe (Rimbu et al., 2001). Stable regions can be detected near Spain and Portugal and near the Scandinavian Peninsula (Fig. 8b). The precipitation variability in these regions is also strongly related to the NAO (Hurrel, 1995). Furthermore, a very large area of AO stability is located in Central Europe (Fig. 8a) consistent with a strong AO-precipitation relationship over the Balkan peninsula (Cavazos, 2000). 25 Our correlation map also indicates positive correlations and an "island of stability" of AO teleconnections over part of China. Over North America, some grid points on the east and west coast show no shifts in the correlation with the $A O$ index. During boreal spring, an area around $40^{\circ} \mathrm{N}$ and $120^{\circ} \mathrm{W}$, the Black Sea area, and some parts
$1,17-56,2005$

\section{Optimal sites for AO} reconstruction

G. Lohmann et al.

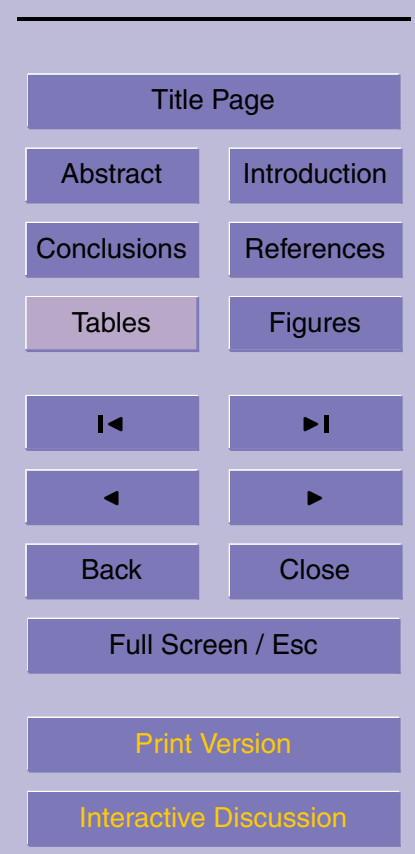


of Europe have stable AO teleconnections (Fig. 9). The correlation can be increased by combining the information from three different locations within "islands of stability" (Fig. 10).

\subsection{Stability of teleconnections: proxy data}

5 In order to analyze the stability of teleconnections using proxy data, we evaluate correlation and stability maps for climate reconstructions from corals (Felis et al., 2000, Evans et al., 2002), ice cores (Appenzeller et al., 1998; Vinther et al., 2003), tree rings (Cook et al., 2002), stalagmites (Proctor et al., 2000), mollusk shells (Schöne et al., 2003), combined tree ring and ice core data (Glueck and Stockton, 2001).

Figure 11 shows boreal winter (January/February) stability maps for the northern Red Sea coral data (Felis et al., 2000) for the period 1856-1995. The coral $\delta^{18} \mathrm{O}$ reflect the local temperature, but also cold air advection from the north which is a regional manifestation of the AO/NAO (Rimbu et al., 2001b). The main features of the largescale AO/NAO teleconnections are represented in the northern Red Sea coral data 15 (Fig. 11a). However, the typical tripole pattern in the western North Atlantic shows some displacements in the correlation south of Greenland and south of $20^{\circ} \mathrm{N}$. Furthermore, the stability regions in the eastern and tropical North Pacific are not represented when compared to the corresponding AO-stability map (Fig. 2).

The stability map for the Greenland ice cores (Appenzeller et al., 1998) indicates record for climate reconstruction purposes. More recent ice core data resolving the seasons is applied (Vinther et al., 2003) for the period 1856-1970. The corresponding maps show the typical tripole pattern in the western North Atlantic and a very stable region in the North Sea, western Europe, and the Red Sea area (Fig. 12). The SST
$1,17-56,2005$

Optimal sites for AO reconstruction

G. Lohmann et al.

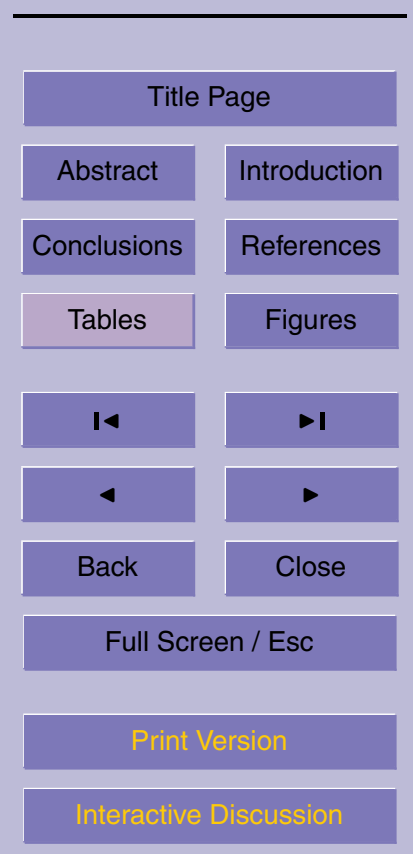


Recently, high-resolution marine proxies from mullusk shells Arctica islandica in boreal and temperate regions have been analyzed (Schöne et al., 2003). The stability map of a time series from the central North Sea show large areas in the North Atlantic with stable SST teleconnections (Fig. 13), indicating that this proxy is suitable 5 for reconstructing large-scale climate variability. The AO stability maps (Figs. 2 and 4) suggest furthermore that the shell from the central North Sea is a sensitive measure for the AO phenomenon.

The corresponding analysis for stalagmite data from Scotland (Proctor et al., 2000) indicates areas of significant positive correlations south of Greenland, the eastern 10 Mediterranean, and the western tropical Atlantic Ocean (Fig. 14a). Negative correlations are detected over the North Sea area, south of India, and at the western Pacific Ocean. Stable teleconnections are seen (Fig. 14b) in the region south of Greenland and some points in the Red Sea, the tropical Pacific, and the tropical east Atlantic. It is possible that the uncertain seasonality for stalagmite data provides for this telecon15 nection pattern.

\subsection{Stability of AO/NAO teleconnections: reconstructions}

Besides the analysis of proxy data, it is furthermore useful to investigate the stability of climate mode reconstructions. Cook et al. (2002) presented an NAO reconstruction based on tree-ring records, six from eastern North America and four from northwestern 20 Europe. The reconstructed series spans the interval AD 1701-1980 and explains 41\% of the variance in the NAO over the AD 1874-1980 calibration period. The correlation and stability map (Fig. 15) shares most of the features as the corresponding maps for the AO (Figs. 2 and 4). Another reconstruction by Glueck and Stockton (2001) based their time series on tree-ring chronologies from Morocco and Finland, GISP2 annual 25

$\delta^{18} \mathrm{O}$ series, and a GISP2 snow accumulation record. We find that these records give different results for the stability of teleconnections. The tree-ring-based NAO index of Cook et al. (1998) indicates a stable teleconnection in the North Atlantic (Fig. 15), whereas the reconstruction of Glueck and Stockton (2001) based on tree ring and ice 
core data, shows almost no stable teleconnection with SST (not shown). Exceptions are in the central Mediterranean, around Japan, and in the Gulf of Mexico. The different stability maps are interesting since the Cook et al. (2002) and Glueck and Stockton (2001) reconstructions are not independent, they share common predictors.

$5 \quad$ For each of the fields analyzed in Sect. 3, the AO is associated with several "islands of stability". In order to improve a climate reconstruction, one should use reconstructions from as many stability islands as possible. In this way the $\mathrm{AO}$ signal can be maximized relative to the signature of other climate modes. This aspect was emphasized through the combination of climate time series shown in Figs. 7 and 10. Here, we 10 want to use the information of the stability maps to provide a new reconstruction by the combined use of the boreal winter northern Red Sea coral data (Felis et al., 2000), ice core data (Vinther et al., 2003), and coral data from the tropical Pacific (Evans et al., 2000). The later source of data has been used to define an SST index over the region $\left(160^{\circ} \mathrm{W}-120^{\circ} \mathrm{W} ; 0-15^{\circ} \mathrm{N}\right)$ which has stable teleconnections with the AO phenomenon 15 during the instrumental period (Figs. 2 and 4). The corresponding maps (Fig. 16) indicate strong and stable teleconnctions in the Pacific Ocean and some areas in the Atlantic and Indian Oceans.

The three time series displayed in Fig. 17a are used to calculate an EOF (Fig. 17b) for the common period 1800-1970. The time series share common variance and a 31-yr running correlations between PC1 and the three time series indicate very stable correlations of PC1 with the boreal winter northern Red Sea coral data (Felis et al., 2000), ice core data (Vinther et al., 2003), and some modulations in the strength of the correlation with the tropical Pacific Ocean SST index (Fig. 17c). The relative small correlation during 1900-1925 is linked to modulations of the tropical-extratropical teleconnctions on multidecadal time scales which is subject a forthcomming paper. The PC1 timeseries (Fig. 17b) is then analyzed with respect to the correlations and regions of stability (Fig. 18). The figures reveal strong similarity with Figs. 2 and 4, especially in the Atlantic Ocean.
$1,17-56,2005$

\section{Optimal sites for AO} reconstruction

G. Lohmann et al.

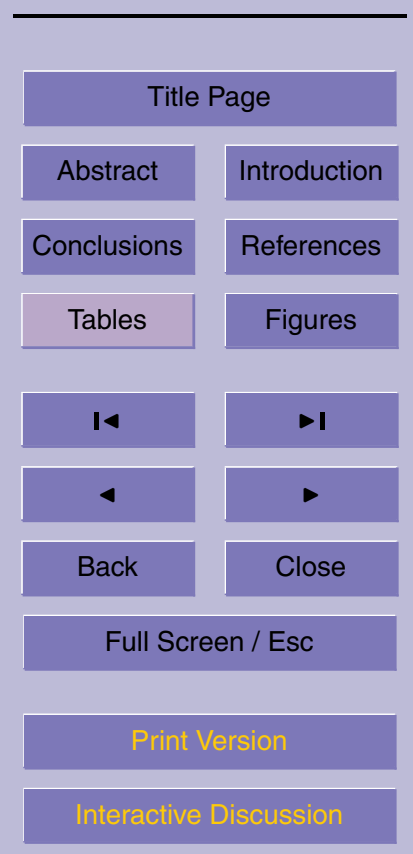




\section{Discussion}

4.1. Islands of stability

$1,17-56,2005$

We investigate the stability of $\mathrm{AO}$ teleconnections over the instrumental period. It appears that the teleconnections with SST are stable over large parts of the North Atlantic, 5 and Middle East, as well as over parts of the Pacific Ocean (Fig. 2). The variations of the surface temperature over land are stable relative to $A O$ over large parts of Europe and northwestern Asia, as well as over some regions of America (Fig. 5). During positive $A O$ phases, warmer than normal temperatures are observed over central/northern Europe and over northern Asia during boreal winter and spring (Figs. 5a and 6a).

10 Around Turkey and the Labrador Sea, temperatures are negatively correlated with the $\mathrm{AO}$ index (Fig. 5a). For the boreal winter, most of these regions also show no shifts in correlation (Fig. 5b).

In particular, the northern Red Sea provides an area of stable teleconnections during the instrumental period and this corroborates studies that linked variability documented in a Red Sea coral to the AO/NAO (Rimbu et al., 2001a; Felis et al., 2004). The stable region over the eastern tropical Pacific is due to the tendency of the $A O$ to be in its negative phase in connection with La Niña conditions in the tropical Pacific (Pozo-Vazquez et al., 2001). The strong teleconnection in the tropical Pacific Ocean is consistent with significant connections to the mid-latitude atmospheric circulation, 20 particularly in winter (Hamilton, 1988). Notable is a tendency for the climatological standing wave pattern over the North Pacific and North America to intensify during the warm tropical conditions associated with ENSO events (Wallace and Gutzler, 1981; Rimbu et al., 2003). The increased prominence of the SST stability region during spring is consistent with tropical North Atlantic SST anomalies associated with SST forcing in the tropical Pacific.

For precipitation (Fig. 8), the most stable regions connected to the $\mathrm{AO}$ are over central and southern Europe (dry conditions for the positive phase of the $\mathrm{AO}$ ) and over northern Europe, over Scandinavia and Scotland (wet conditions for the positive phase

Optimal sites for $\mathrm{AO}$ reconstruction

G. Lohmann et al.

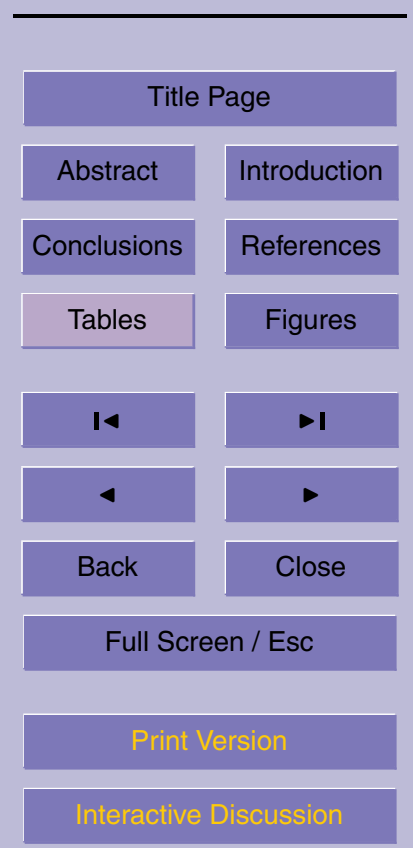


of $\mathrm{AO}$ ). The correlation pattern is similar to the second mode of decadal precipitation anomalies over Europe (Rimbu et al., 2001b). The composite map of SLP based on a PP index over central Europe resembles the annular mode (an AO-like pattern), whereas the large-scale pattern associated with precipitation variability over the Scan5 dinavian peninsula resembles more the dipole pattern over the North Atlantic realm (NAO-like).

Recent studies identified the signature of the $\mathrm{AO}$ in East Asian winter temperature and precipitation. The temperature pattern associated with the AO for the period 19001998 is very similar to that identified by Gong and Wang (2003), although theirs is for 10 the 1948-2000 period. This suggests that this temperature pattern is stable related to the period considered in the analysis, consistent with the indications of our stability map for temperature (Fig. 5b). Positive correlations between the winter AO index and precipitation for the period 1958-1999 dominate a large part of China (Gong and Wang, 2003), consistent with the existence of an "island of stability" of AO teleconnections in

15 this region (Fig. 8b). Interestingly, much proxy data covering the last two millennia exists over this area (Yang et al., 2002).

\subsection{Seasonality}

It is interesting to observe how the extents of the stability regions change from winter to spring. For surface temperature (Figs. 5 and 6) and precipitation (Figs. 8 and 9), the 20 stability regions are reduced in spring relative to the winter season, consistent with the relatively small decorrelation time in the atmosphere. This is in contrast to SST, where the Atlantic stability regions are increased in spring (Fig. 4b) relative to winter (Fig. 2b). The heat capacity of the mixed layer and the atmospheric dynamics are necessary to strengthen the winter signal. This is supported by model simulations (Saravanan 25 and Chang, 2000), which indicate that the strongest response to boreal winter SST anomalies in the tropical Pacific is delayed by several months over the Atlantic, where the most significant influence is found during boreal spring.
$1,17-56,2005$

Optimal sites for AO reconstruction

G. Lohmann et al.

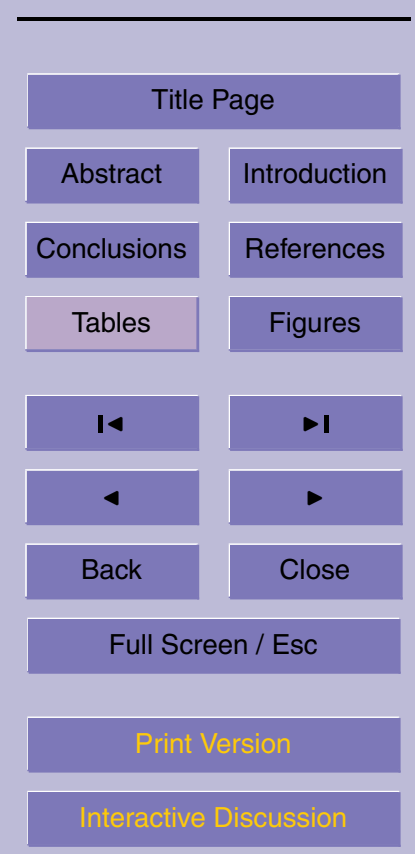




\subsection{Climate regimes}

The question of possible sites for climate reconstructions is also related to different regimes of the dominant modes of climatic variability. Walter and Graf (2002) show that there are two distinct periods of the NAO: a period from 1930 to 1960 when NAO

5 had a weak decadal and strong interannual variability, and a period after the $1970 \mathrm{~s}$ with strong decadal variability. In the 1930 to 1960 period, the teleconnections are more hemispheric (AO-like) with an emphasized seesaw between the Mediterranean and the polar regions (Kodera and Kuroda, 2003). Also the large-scale teleconnections were different during these periods as obtained from instrumental (Knippertz et al., 2003) and proxy data (Rimbu et al., 2003), which is possibly linked to multidecadal climate variability (Lohmann et al., 2004).

An alternative way of determining the best sites for reconstructing atmospheric modes via stable teleconnections is through long-term integrations using climate models. We carried out the procedure for determining regions with stable teleconnections in a 2300-year control integration with the coupled atmosphere-ocean-sea ice model ECHO-G (Lorenz and Lohmann, 2004). The basic results remain valid (not shown) and is consistent with decadal modulation of the signal communication between the Pacific and Atlantic Oceans in a control integration by Raible et al. (2001). We note, however, that the exact structure of teleconnection patterns are not captured by the model, which could be due to model deficiencies in simulating Northern Hemisphere circulation regimes. It is conceivable that the model grid resolution (T30) is not high enough to resolve the dynamical and geographical details. For example, teleconnection patterns over Europe seem sensitively dependent on the model resolution (e.g. Merkel and Latif, 2002). We have therefore confined our investigation to the stability of
1, 17-56, 2005

Optimal sites for AO reconstruction

G. Lohmann et al.

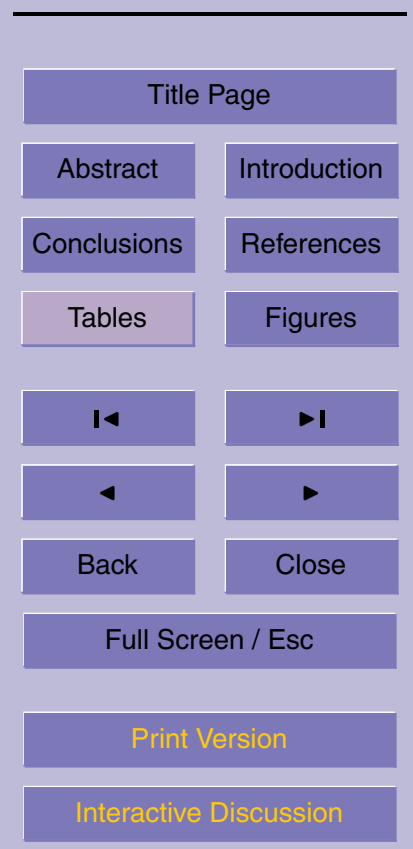


Until now, the AO/NAO reconstructions have been solely based on the correlation with

SLP indices and comparison with spectral characteristics. Schmutz et al. (2000) compared different reconstructions of the NAO index and found that the various existing 5 NAO index reconstructions show an inconsistent picture which can be attributed to non-stationarity in the statistical relationships. Recently, Timm et al. (2004) pointed out the time-dependent relations among the different NAO reconstructions and suggested that the geographical distribution of proxies strongly affects the reconstructions and could explain some of the apparent discrepancies among the reconstructions recently 10 published in the literature. With our approach we systematically analyze the quality of the geographical location for the AO/NAO. We suggest that a proxy data set suitable for reconstructing large-scale climate modes should have large-scale stable teleconnections as indicated by large "islands of stability". An analysis solely based on the correlation of proxy time series with climate indices does not account for shifts in cor-

15 relation and does not take into account that proxy indices may be affected by several modes of variability on different timescales. More information from independent paleoclimatic archives may improve a climate reconstruction. We argue that for each time series a statistical analysis of teleconnections should precede a compilation based on a multi-proxy approach. Only stable teleconnections can yield an improved record of $20 \mathrm{AO} / \mathrm{NAO}$ variability. The identification of shifts is furthermore important to better understand the underlying dynamics associated with this mode of climatic variability.

In order to improve the $A O$ reconstruction presented in Figs. $17 \mathrm{~b}$ and 18 for the Pacific sector, one needs high resolution proxy data from the "islands of stability" in the tropical Pacific Ocean (Figs. 2 and 4). An additional analysis with the Maiana coral 25 record (Urban et al., 2000) included in our reconstruction, shows an improvement in the teleconnections for the Pacific Ocean (not shown). However, this record covers the instrumental period only. An inproved AO reconstruction beyond the instrumental record would require seasonal resolved proxy data in the tropical Pacific Ocean which

Optimal sites for AO reconstruction

G. Lohmann et al.

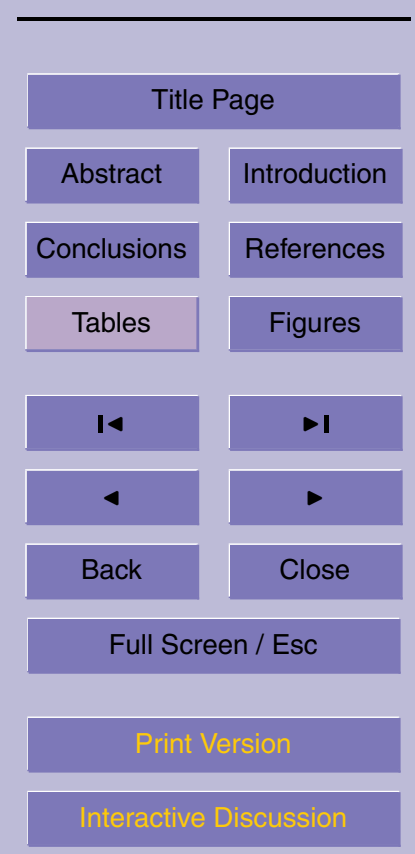




\section{Conclusions}

Thompson et al. (2000) emphasized the remarkable similarity between recent climate trends and the structure of the AO pattern, defined as the first EOF of 20th-century SLP.

5 The index of this Northern Hemisphere annular mode has exhibited a trend toward the high side over the past few decades, corresponding to an SLP decrease over the pole and an increase in the subtropics. Unfortunately, historical records that would allow consideration of changing climate on a global scale are too short and already fall within the period of strong human impact on natural conditions. Information on earlier times 10 can be obtained from proxies that record past climatic and environmental conditions and bring the climate of the last century into a long term context.

The signature of the AO/NAO has been detected in proxy data on interannual to millennial time scales (White et al., 1997; Cook et al., 2002; Appenzeller et al., 1998; Rimbu et al., 2001a; Schöne et al., 2003; Vinther et al., 2003; Felis et al., 2004). How15 ever, the reconstruction of climate modes using proxy and instrumental climate data is limited by the non-stationary behavior of the teleconnections (Fischer, 2001; Rimbu et al., 2003). Here, we depict a systematic approach reconstructing climate modes such as the AO. Our method is based on constructing moving correlation coefficients between the $\mathrm{AO}$ index and climate data, providing the number of shifts (i.e. change in the sign of the correlation between $\mathrm{AO}$ and the field anomaly time series) recorded at each grid point. The method of looking for stable teleconnections may also be used for prediction purposes but that is beyond the scope of this paper.

The AO teleconnections related to temperature show weak decadal variations in regions of the North Atlantic and Pacific. Weak decadal variability in the AO-precipitation 25 relationship is detected over southern Europe, northwestern Europe, parts of China and North America. The AO signature in climate variables is also detectable during the spring season, which is of practical relevance since the climate information obtained

Optimal sites for AO reconstruction

G. Lohmann et al.

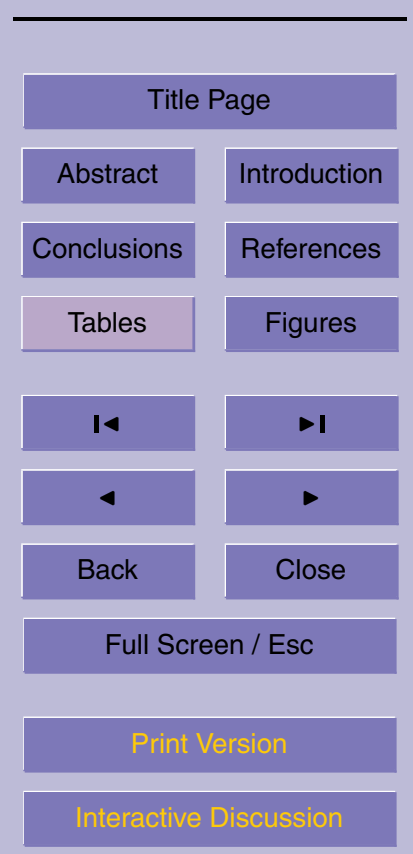


from terrestrial and marine organisms is more linked to the growing/blooming period of the year than to winter (Cook et al., 2002; Conte et al., 1992). Interestingly, the sites for possible reconstructions shrink from boreal winter to summer for surface temperature and precipitation over land, whereas they increase for SST. This implies a potential 5 for AO reconstructions in the North Atlantic based on marine proxies that sensitively depend on spring temperatures.

Because of their high quality, reanalysis data are quite often used for reconstructions in connection with proxy data ("upscaling technique"). However, the climate of the last 50 years may be not representative in the long-term context due to shifts in telecon10 nection pattern which occured in the 1920s and 1970s (e.g. Fischer, 2001; Rimbu et al., 2003). We identified Northern Hemisphere regions where the AO/NAO teleconnections shows weak decadal variations. Temperature and precipitation sensitive proxy data from the "islands of stability" can be used to reconstruct late Holocene climate variability. We applied our approach to annually resolved archives from corals, ice 15 cores, tree rings, and mollusk shells and show that stable teleconnections are one important criterion for climate reconstruction based on proxy data. In our approach, we concentrate on natural proxy data. There are other high resolved indirect climate information for instance from historical documentary records going far back in time, for precipitation (e.g., Rodrigo et al., 2001), for temperature (e.g., Mann, 2002), for circulation reconstructions (e.g., Luterbacher et al., 2002), for the western Baltic winter sea ice index (Koslowski and Glaser, 1999). Such information will be investigated in future work since part of the data cover "optimal sites" related to the climate modes investigated. A logical next step would be to use a combination of annually resolved archives and these climate informations in order to test coupled atmosphere-ocean general cir-

Acknowledgements. This work was supported by Bundesministerium für Bildung und Forschung through DEKLIM and the Alfred Wegener Institute, and by Deutsche Forschungsgemeinschaft through DFG Research Center Ocean Margins at Bremen University. MD received support from the Alexander von Humboldt-Foundation. Thanks go to the data contributors and 
to S. Lorenz for providing model data. D. Thresher and M. Prange are acknowledged for their suggestions to the manuscript.

\section{References}

Appenzeller, C., Stocker, T. F., and Anklin, M.: North Atlantic Oscillation dynamics recorded in Greenland ice cores, Science, 282, 446-449, 1998.

Baldwin, M. P. and Dunkerton, T. J.: Propagation of the Arctic Oscillation from the stratosphere to the troposphere, J. Geophys. Res., 104, 937-946, 1999.

Cavazos, T.: Using self-organizing maps to investigate extreme climate events: An application to wintertime precipitation in the Balkans, J. Climate, 13, 1718-1732, 2000.

10 Conte, M. H., Egliton, G., and Madureira, A. A. S.: Long chain alkenons and alkyl alkenoates as palaeotemperature indicators: their production, flux and early sedimentary diagenesis in the eastern North Atlantic, Org. Geochem., 19, 287-298, 1992.

Cook, E. R., D'Arrigo, R. D., and Briffa, K. R.: A reconstructed of North Atlantic Oscillation using tree-ring chronologies from North America and Europe, The Holocene, 8, 9-17, 1998.

15 Cook, E. R., D'Arrigo, R. D., and Mann, M. E.: A Well-Verified, Multiproxy Reconstruction of the Winter North Atlantic Oscillation Index since A.D. 1400, J. Climate, 15, 1754-1764, 2002.

Defant, A.: Die Schwankungen der atmosphärischen Zirkulation über dem nordatlantischen Ozean im 25-jährigen Zeitraum 1881-1905, Geogr. Annaler, 6, 13-41, 1924.

Deser, C.: On the teleconnectivity of the "Arctic Oscillation", Geophys. Res. Lett., 27, 779-782, 2000.

Evans, M. N., Kaplan, A., and Cane, M. A.: Intercomparison of coral oxygen isotope data and historical sea surface temperature (SST): Potential for coral-based SST field reconstructions, Paleoceanography, 15, 551-563, 2000.

Evans, M. N., Kaplan, A., and Cane, M. A.: Pacific sea surface temperature field reconstruction from coral delta 180 data using reduced space objective analysis, Paleoceanography, 17, 1007, doi:10.1029/2000PA000PA000590, 2002.

Felis, T., Pätzold, J., Loya, Y., Fine, M., Nawar, A. H., and Wefer, G.: A coral oxygen isotope record from the northern Red Sea documenting NAO, ENSO, and North Pacific teleconnections on Middle East climate variability since the year 1750, Paleoceanography, 15, 679-694, 2000.
$1,17-56,2005$

\section{Optimal sites for AO} reconstruction

G. Lohmann et al.

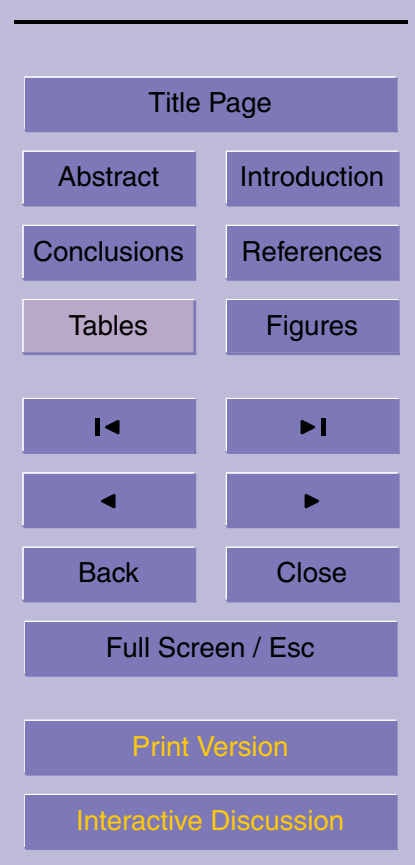


Felis, T., Lohmann, G., Kuhnert, H., Lorenz, S., Scholz, D., Pätzold, J., Al-Rousan, S. A., and Al-Moghrabi, S. M.: Increased seasonality in Middle East temperatures during the last interglacial period, Nature, 429, 164-168, 2004.

Fischer, H.: Imprint of large-scale atmospheric transport patterns on sea-salt records in northern Greenland ice cores, J. Geophys. Res., 196, 23 977-23 984, 2001.

Gershunov, A., Schneider, N., and Barnett, T.: Low-Frequency Modulation of the ENSO-Indian Monsoon Rainfall Relationship: Signal or Noise? J. Climate, 14, 2486-2492, 2001.

Glowienka, R.: Studies on the variability of Icelandic Low and Azores High between 18811983, Contrib. Atmos. Phys., 58, 160-170, 1985.

10 Glowienka-Hense, R.: The North Atlantic Oscillation in the Atlantic-European SLP, Tellus 42A, 497-507, 1990.

Glueck, M. F. and Stockton, C. W.: Reconstruction of the North Atlantic Oscillation, Int. J. Climatol., 21, 1453-1465, 2001.

Gong, D. Y. and Wang, S. W.: Influence of Arctic Oscillation on winter climate over China, J.

15 Geograph. Sci., 13, 208-216, 2003.

Hamilton, K.: A detailed examination of the extratropical response to tropical El Niño/Southern Oscillation events, Int. J. Climatol., 8, 67-86, 1988.

Hansen, J., Ruedy, R., Sato, M., Imhoff, M., Lawrence, W., Easterling, D., Peterson, T., and Karl, T.: A closer look at United States and global surface temperature change, J. Geophys. Res., 106, 23947-23 963, 2001.

Hendy, E. J., Gagan, M. K., and Lough, J. M.: Chronological control of coral records using luminescent lines and evidence for non-stationary ENSO teleconnections in northeast Australia, The Holocene, 13, 187-199, 2003.

Hurrell, J. W.: Decadal trends in the North Atlantic Oscillation: Regional temperatures and precipitation, Science, 269, 676-679, 1995.

Hulme, M. and New, M.: The dependence of large-scale precipitation climatologies on temporal and spatial gauge sampling, J. Climate, 10, 1099-1113, 1997.

Jones, P. D.: Hemispheric surface air temperature variations: a reanalysis and an update to 1993, J. Climate, 7, 1794-1802, 1994.

30 Jones, P. D., Jonsson, T., and Wheeler, D.: Extension to the North Atlantic Oscillation using early instrumental pressure observations from Gibraltar and south-west of Iceland, Int. J. Climatol., 17, 1433-1450, 1997.

Jones, P. D. and Moberg, A.: Hemispheric and large-scale surface air temperature variations: 
An extensive revision and an update to 2001, J. Climate, 16, 206-223, 2003.

Kaplan, A., Cane, M., Kushnir, Y., Clement, A., Blumenthal, M., and Rajagopalan, B.: Analyses of global sea surface temperature 1856-1991, J. Geophys. Res., 103, 18567-18589, 1998.

Knippertz, P., Ulbrich, U., Marques, F., and Corte-Real, J.: Decadal changes in the link between

$5 \quad$ El Niño and springtime North Atlantic Oscillation and European-North African rainfall, Int. J. Climatol. 23, 1293-1311, 2003.

Kodera, K.: On the origin and nature of the interannual variability of the winter stratosphere and troposphere in the Northern Hemisphere, J. Geophys. Res., 100, 14 077-14 087, 1995.

Kodera, K. and Kuroda, Y.: Regional and hemispheric circulation patterns in the northern hemisphere winter, or the NAO and the AO, Geophys. Res. Lett., 30, 1934, doi:10.1029/2003GL017290, 2003.

Koslowski, G. and Glaser, R.: Variations in reconstructed Ice winter severity in the Western Baltic from 1501 to 1995 , and their implications for the North Atlantic Oscillation, Clim. Change, 41, 175-191, 1999.

Kutzbach, J. E.: Large-scale features of monthly mean Northern Hemisphere anomaly maps of sea-level pressure, Mon. Wea. Rev., 98, 708-716, 1970.

Lohmann, G., Rimbu, N., and Dima, M.: Climate signature of solar irradiance variations: Analysis of long-term instrumental, historical, and proxy data, Int. J. Clim., 24, 1045-1056, doi:10.1002/joc.1054, 2004.

20

Lorenz, S. and Lohmann, G.: Acceleration technique for Milankovitch type forcing in a coupled atmosphere-ocean circulation model: method and application for the Holocene, Climate Dyn., 23, 727-743, 2004, doi:10.1007/s00382-004-0469-y, 2004.

Luterbacher, J., Schmutz, C., Gyalistras, D., Xoplaki, E., and Wanner, H.: Reconstruction of monthly NAO and EU indices back to AD 1675, Geophys. Res. Lett., 26, 2745-2748, 1999.

Luterbacher, J., Xoplaki, E., Dietrich, D., Rickli, R., Jacobeit, J., Beck, C., Gyalistras, D., Schmutz, C., and Wanner, H.: Reconstruction of Sea Level Pressure fields over the Eastern North Atlantic and Europe back to 1500, Clim. Dyn., 18, 545-561, 2002.

Mann, M. E., Bradley, R. S., and Hughes, M. K.: Global-scale temperature patterns and climate forcing over the past six centuries, Nature, 392, 779-787, 1998.

30 Mann, M. E., Bradley, R. S., and Hughes, M. K.: Northern Hemisphere temperatures during the past millennium: inferences, uncertainties, and limitations, Geophys. Res. Lett., 26, 759$762,1999$.

Mann, M. E.: The value of multiple proxies, Science, 297, 1481-1482, 2002.
$1,17-56,2005$

Optimal sites for AO reconstruction

G. Lohmann et al.

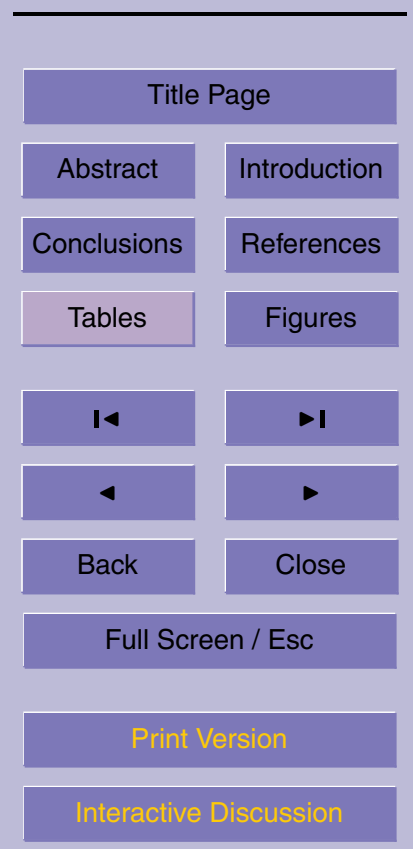


Merkel, U. and Latif, M.: A high resolution AGCM study of El Niño impact in the North Atlantic/European sector, Geophys. Res. Lett., 29, 1-4, 2002.

Pauling, A., Luterbacher, J., and Wanner, H.: Evaluation of Proxies for European and North Atlantic Temperature Field Reconstructions, Geophys. Res. Lett., 30, 1787, doi:10.1029/2003GL017589, 2003.

Perlwitz, J. and Graf, H.-F.: The statistical connection between tropospheric and stratospheric circulation of the Northern Hemisphere in winter, J. Climate, 8, 2281-2295, 1995.

Proctor, C. J., Baker, A., Barnes, W. L., and Gilmour, M. A.: A thousand year speleothem proxy record of North Atlantic climate from Scotland, Clim. Dyn., 16, 615-620, 2000.

10 Pozo-Vazques, D., Esteban-Parra, M. J., Rodrigo, F. S., and Castro-Diez, Y.: The association between ENSO and winter atmospheric circulation and temperature in the North Atlantic region, J. Climate, 16, 3408-3420, 2001.

Raible, C., Luksch, U., Fraedrich, K., and Voss, R.: North Atlantic decadal regimes in a coupled GCM simulation, Clim. Dyn., 18, 321-330, 2001.

15 Rayner, N. A., Parker, D. E., Horton, E. B., Folland, C. K., Alexander, L. V, Rowell, D. P., Kent, E. C., and Kaplan, A.: Globally complete analyses of sea surface temperature, sea ice and night marine air temperature, 1871-2000, J. Geophys. Res., 108, 4407, doi:10.1029/2002JD002670, 2003.

Rimbu, N., Lohmann, G., Felis, T., and Pätzold, J.: Arctic Oscillation signature in a Red Sea coral, Geophys. Res. Lett., 28, 2959-2962, 2001a.

Rimbu, N., LeTreut, H., Janicot, S., Boroneant, C., and Laurent, C.: Decadal precipitation variability over Europe and its relation with surface atmospheric circulation and sea surface temperature, Q. J. R. Meteorol. Soc., 127, 315-329, 2001b.

Rimbu, N., Lohmann, G., Felis, T., and Pätzold, J.: Shift in ENSO teleconnections recorded by a Red Sea coral, J. Climate, 16, 1414-1422, 2003.

Rodrigo, F. S., Esteban-Parra, M. J., Pozo-Vazquez, D., and Castro-Diez, Y.: A 500-year precipitation record in southern Spain, Int. J. Climatol., 19, 1233-1253, 1999.

Saravanan, R. and Chang, P.: Interaction between tropical Atlantic variability and EI NiñoSouthern Oscillation, J. Climate, 13, 2177-2194, 2000.

30 Schmutz, C., Luterbacher, J., Gyalistras, D., Xoplaki, E., and Wanner, H.: Can we trust proxybased NAO index reconstructions? Geophys. Res. Lett., 27, 1135-1138, 2000.

Schöne, B. R., Oschmann, W., Rössler, J., Freyre Castro, A. D., Houk, S. D., Kröncke, I., Dreyer, W., Janssen, R., Rumohr, H., and Dunca, E.: North Atlantic Oscillation dynamics recorded 
in shells of a long-lived bivalve mollusk, Geology, 31, 1237-1240, 2003.

Smith, T. M. and Reynolds, W. R.: Improved Extended Reconstruction of SST (1854-1997), J. Climate, 17, 2466-2477, 2004.

Thompson, D. W. J. and Wallace, J. W.: The Arctic Oscillation signature in the wintertime geopotential height and temperature fields, Geophys. Res. Lett., 25, 1297-1300, 1998.

Thompson, D. W. J, Wallace, J. W., and Hegerl, G. C.: Annular modes in the extratropical circulation. Part II Trends, J. Climate, 13, 1018-1036, 2000.

Timm, O., Ruprecht, E., and Kleppek, S.: Scale-Dependent Reconstruction of the NAO Index, J. Climate, 17, 2157-2169, 2004.

10 Trenberth, K. E. and Paolino, D. A.: The northern hemisphere sea level pressure data set: Trends, errors and discontinuities, Mon. Wea. Rev., 108, 855-872, 1980.

Urban, F. E., Cole, J. E., and Overpeck, J. T.: Influence of mean climate change on climate variability from a 155-year tropical Pacific coral record, Nature, 407, 989-993, 2000.

Vinther, B. M., Johnsen, S. J., Andersen, K. K., Clausen, H. B., and Hansen, A. W.: NAO signal recorded in the stable isotopes of Greenland ice cores, Geophys. Res. Lett., 30, 2222, doi:10.1029/2003GL018220, 2003.

Wallace, J. M. and Gutzler, D. S.: Teleconnections in the geopotential height field during the Northern Hemisphere winter, Mon. Wea. Rev., 109, 784-812, 1981.

Walter, K. and Graf, H.-F.: On the changing nature of the regional connection between the North Atlantic Oscillation and sea surface temperature, J. Geophys. Res., 107, 4338, doi:10.1029/2001JD000850, 2002.

White, J. W. C., Barlow, L. K., Fischer, D., Grootes, P., Jouzel, J., Johnsen, S. J., Stuiver, M., and Clausen, $\mathrm{H}$.: The climatic signal in the stable isotopes of snow from Summit, Greenland: Results of comparisons with modern climate observations, J. Geophys. Res., 102, 26425 26 440, 1997.

Yang, B., Braeuning, A., Johnson, K. R., and Yafeng, S.: General characteristics of temperature variation in China during the last two millennia, Geophys. Res. Lett., 29, 381-384, doi:10.1029/2001GL014485, 2002.

Zorita, E., and Gonzalez-Rouco, F., Are temperature-sensitive proxies adequate for North Atlantic Oscillation reconstructions? Geophys. Res. Lett., 29, 14, doi:10.1029/2002GL015404, 2002.
$1,17-56,2005$

Optimal sites for AO reconstruction

G. Lohmann et al.

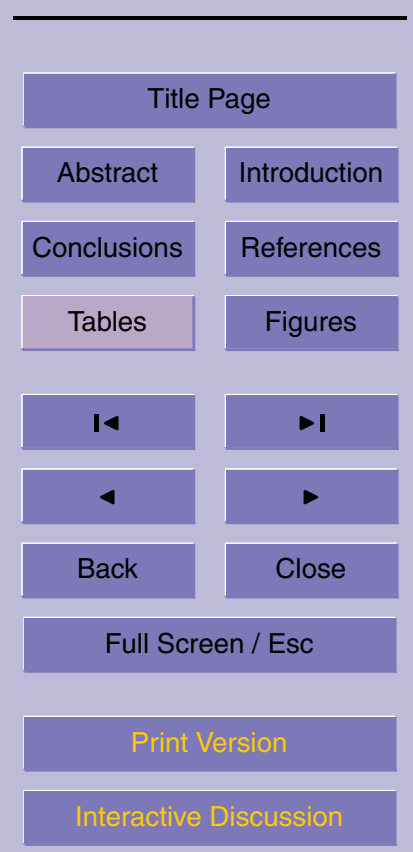


(a)

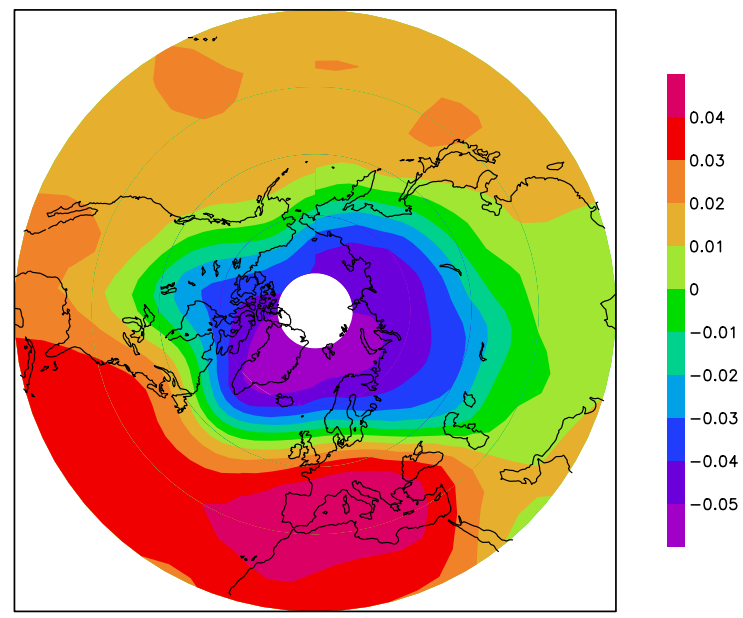

(b)

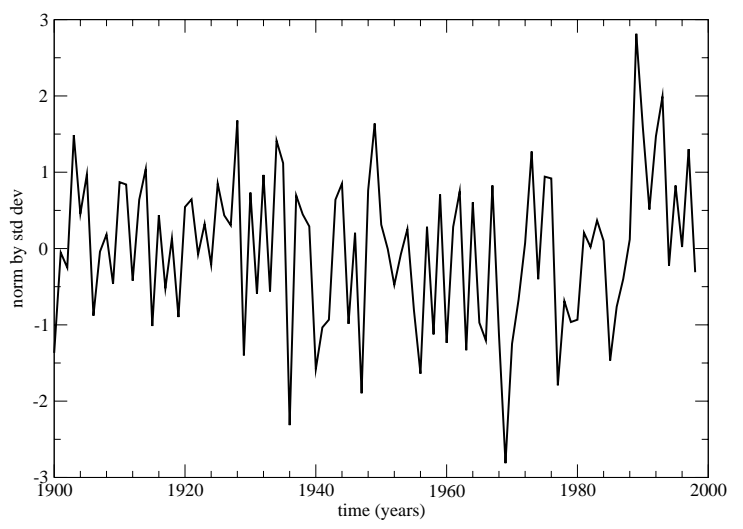

$1,17-56,2005$

\section{Optimal sites for AO} reconstruction

G. Lohmann et al.

\section{Title Page}

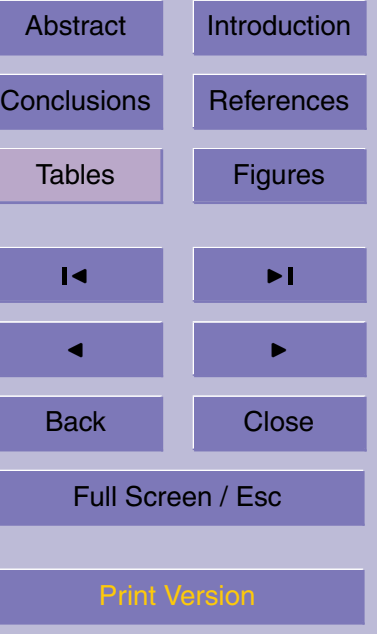

Interactive Discussion

Fig. 1. (a) The first EOF of Northern Hemisphere SLP (Trenberth and Paolino, 1980) during January/February for the period 1900 to 1998; (b) The associated PC that serves as the AO index in this study. 
(a)

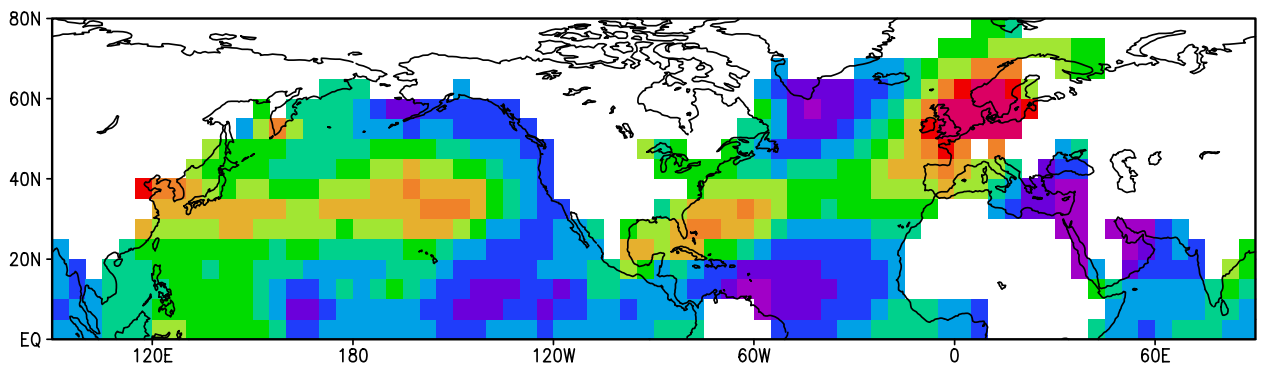

(b)

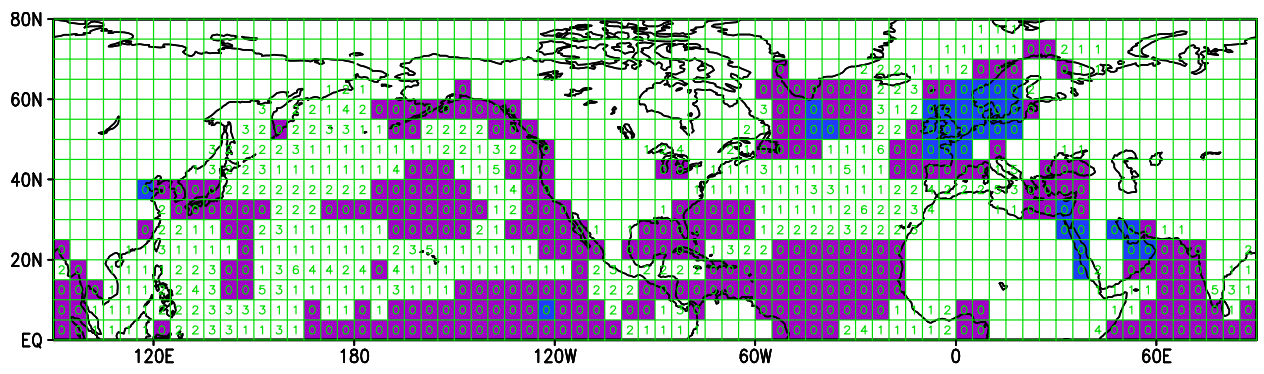

Fig. 2. (a) Correlation between the AO index and boreal winter SST for the period 1900-1998. (b) Number of shifts (i.e. the changes in the sign of the correlation in 31-year moving windows) between the AO index and local SST anomaly time series. Regions where the number of shifts is zero are shaded with blue and mangenta.

$1,17-56,2005$

\section{Optimal sites for AO} reconstruction

G. Lohmann et al.

\section{Title Page}

\section{Abstract}

Introduction

Conclusions

References

Tables

Figures

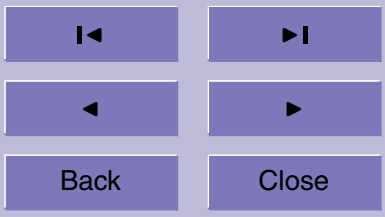

Full Screen / Esc

Print Version

Interactive Discussion 
$1,17-56,2005$

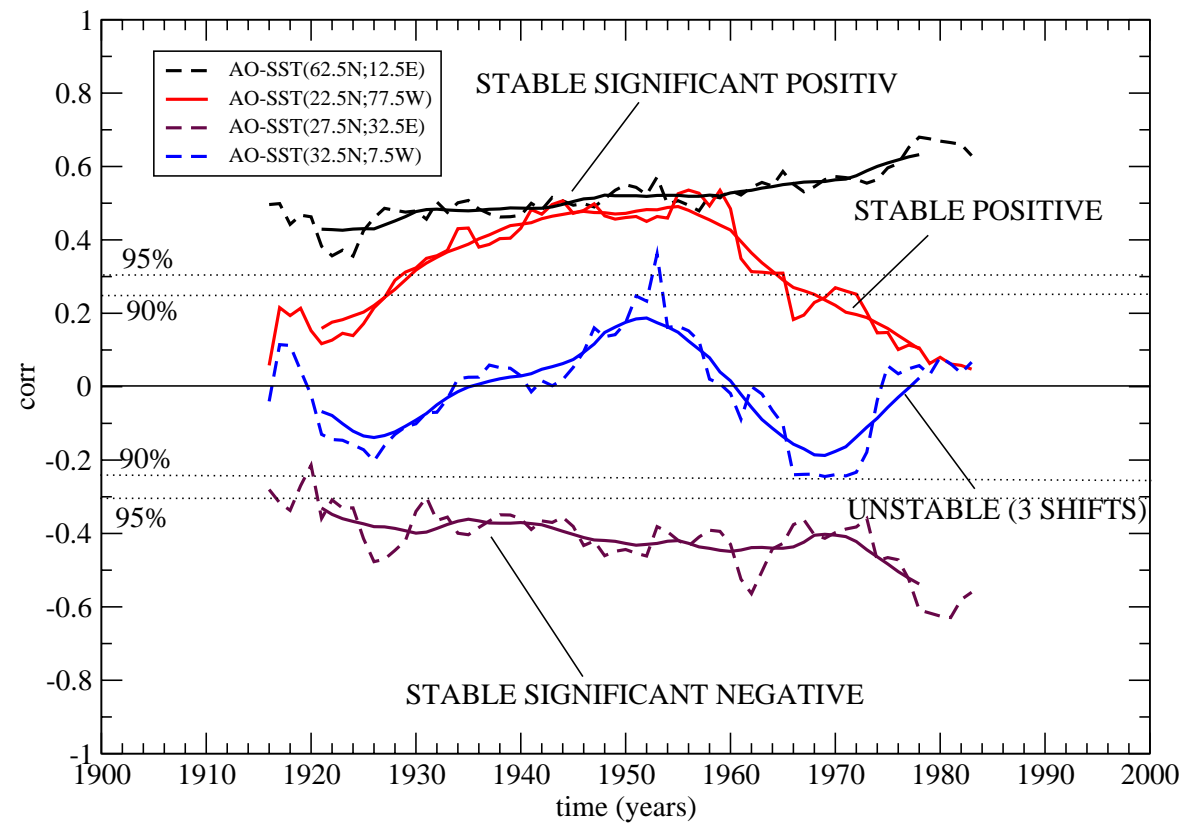

\section{Optimal sites for AO} reconstruction

G. Lohmann et al.

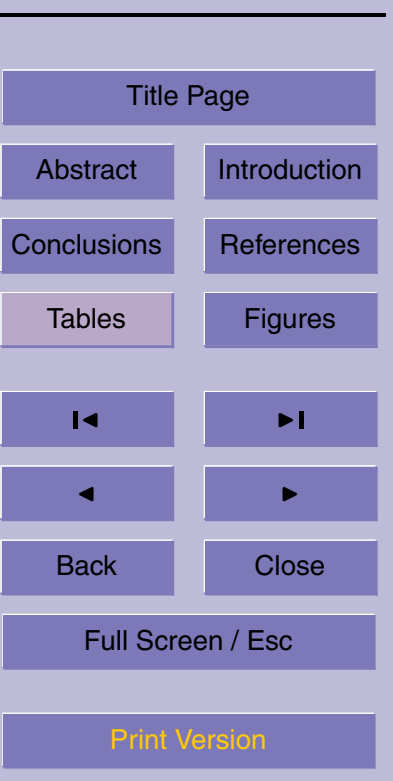

Fig. 3. Running correlation for four sites located in the Atlantic realm. The thick lines represent an 11-year running mean, respectively. If these curves do not go below the $90 \%$-confidence 
(a)

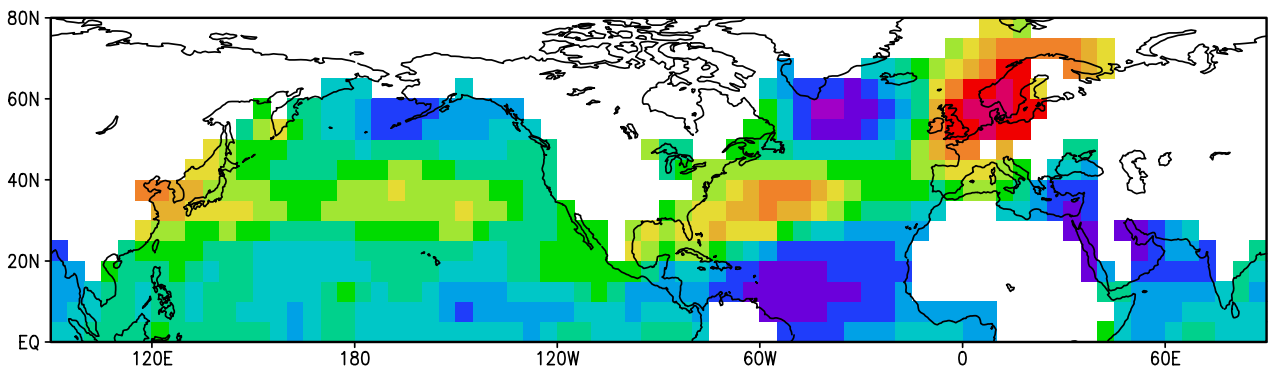

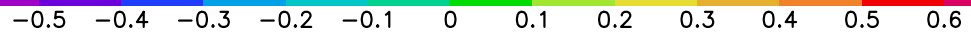

(b)

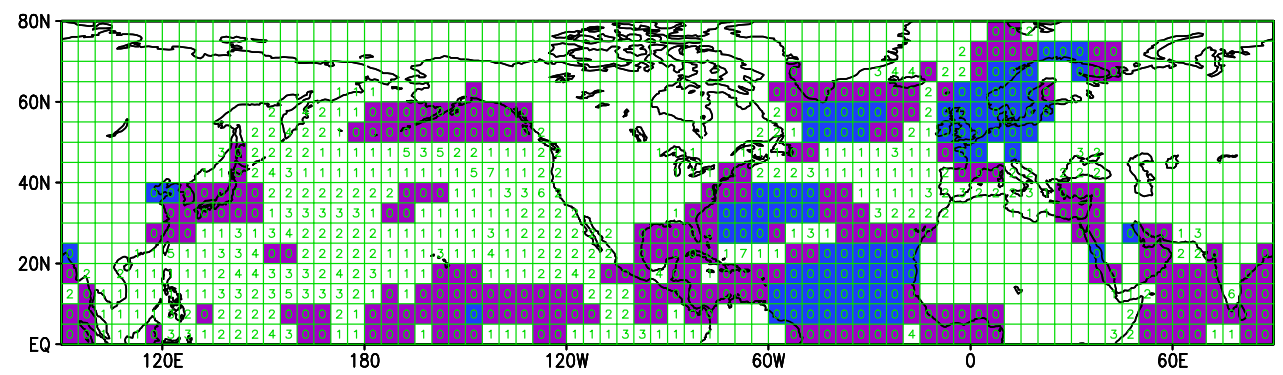

Fig. 4. As in Fig. 2, but for boreal spring SST (March/April).
$1,17-56,2005$

\section{Optimal sites for AO} reconstruction

G. Lohmann et al.

\section{Title Page}

\begin{tabular}{|c|c|}
\hline Abstract & Introduction \\
\hline Conclusions & References \\
\hline Tables & Figures \\
\hline 14 & $\rightarrow 1$ \\
\hline 4 & 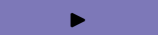 \\
\hline Back & Close \\
\hline \multicolumn{2}{|c|}{ Full Screen / Esc } \\
\hline Print & sion \\
\hline
\end{tabular}

Interactive Discussion 
(a)

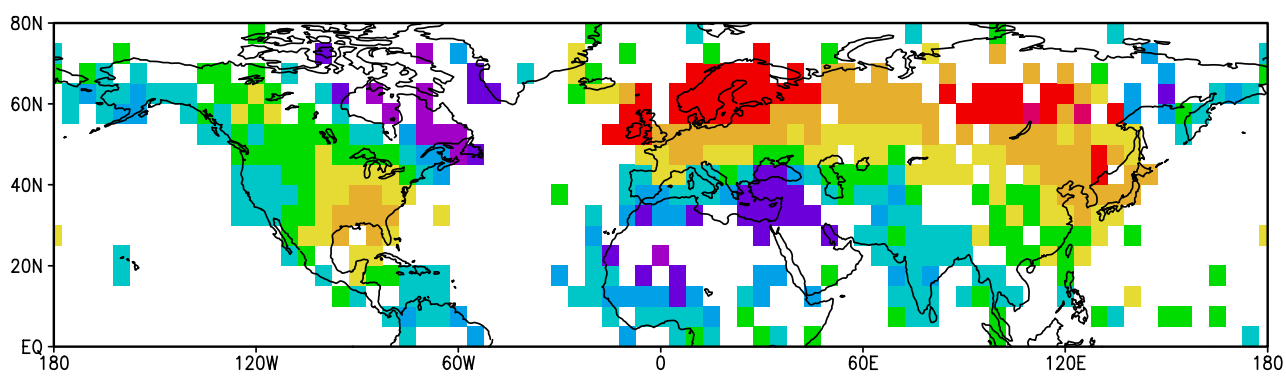

$-0.6$

$-0.4-0.2$
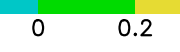

0.4

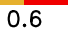

0.8

(b)

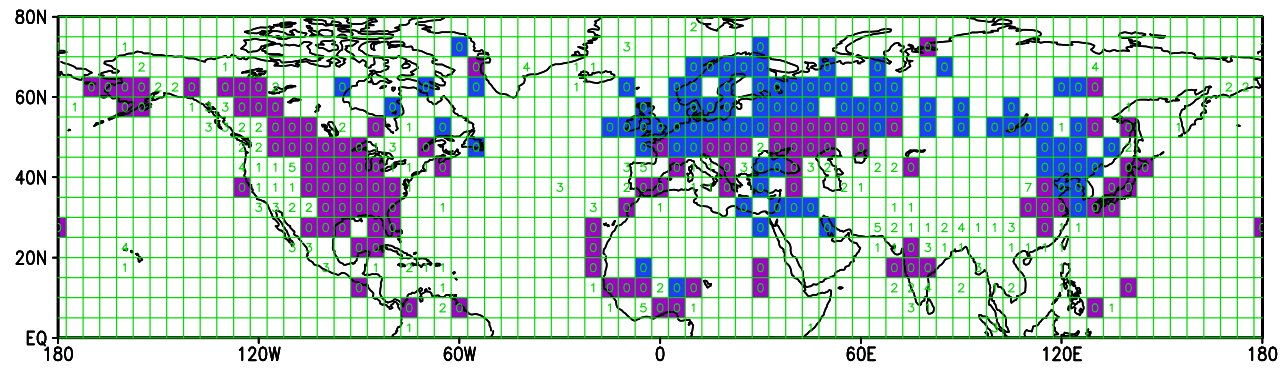

Fig. 5. As in Fig. 2, but for terrestrial surface air temperature (boreal winter). Empty boxes represent areas with insufficient data.
$1,17-56,2005$

\section{Optimal sites for AO reconstruction}

G. Lohmann et al.

\section{Title Page}

\begin{tabular}{|c|c|}
\hline Abstract & Introduction \\
\hline Conclusions & References \\
\hline Tables & Figures \\
\hline 14 & $\rightarrow 1$ \\
\hline 4 & - \\
\hline Back & Close \\
\hline \multicolumn{2}{|c|}{ Full Screen / Esc } \\
\hline Print & sion \\
\hline
\end{tabular}

Interactive Discussion 
(a)

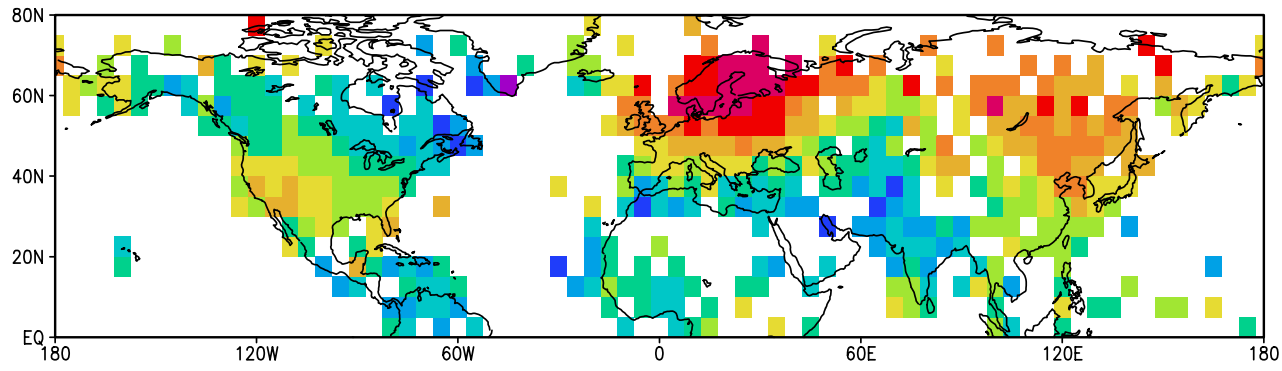

$\begin{array}{lllll}-0.5 & -0.4 & -0.3 & -0.2 & -0.1\end{array}$

0.1

0.2

0.3

0.4

0.5

(b)

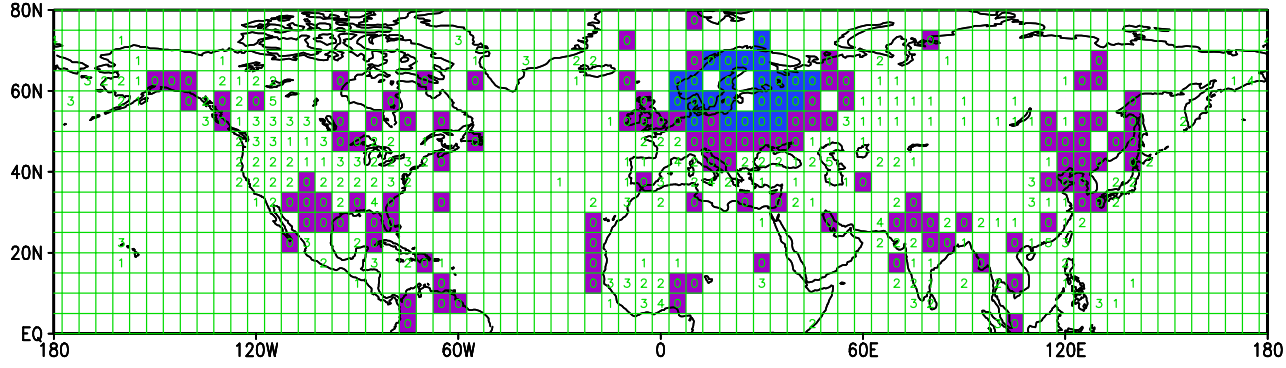

Fig. 6. As in Fig. 5, but for terrestrial surface air temperature during boreal spring.
$1,17-56,2005$

Optimal sites for AO reconstruction

G. Lohmann et al.

Title Page

\begin{tabular}{|c|c|}
\hline Abstract & Introduction \\
\hline Donclusions & References \\
\hline Tables & Figures \\
\hline 14 & $>1$ \\
\hline 4 & 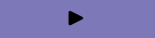 \\
\hline Back & Close \\
\hline
\end{tabular}

Full Screen / Esc

Print Version

Interactive Discussion 


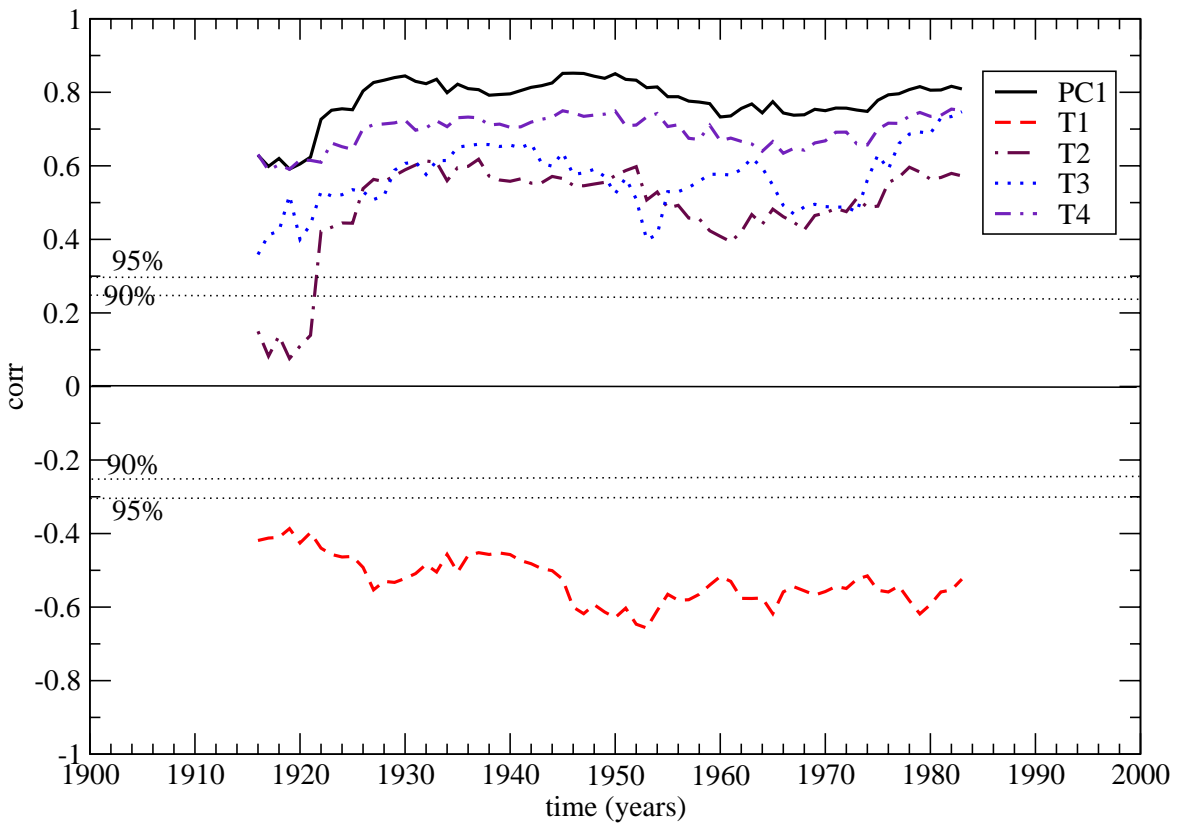

Fig. 7. 31-year window correlations between four Northern Hemisphere winter temperature time series and the AO index. The sites are defined as means over T1: Baltic Sea area $\left(10^{\circ}-25^{\circ} \mathrm{E} ; 55^{\circ}-70^{\circ} \mathrm{N}\right)$, T2: North America $\left(100^{\circ}-85^{\circ} \mathrm{W} ; 30^{\circ}-45^{\circ} \mathrm{N}\right)$, T3: Israel $\left(30^{\circ}-45^{\circ} \mathrm{E} ; 25^{\circ}-\right.$ $\left.40^{\circ} \mathrm{N}\right)$, T4: China $\left(110^{\circ}-125^{\circ} \mathrm{E} ; 35^{\circ}-50^{\circ} \mathrm{N}\right)$. The black curve displays the 31 -year window correlation between the first principal component (PC1) based on the individual temperature time series with the AO index. The correlation between the time series (T1-T4) and PC1 are 0.66, $0.51,-0.55$, and 0.20 , respectively.
$1,17-56,2005$

\section{Optimal sites for AO} reconstruction

G. Lohmann et al.

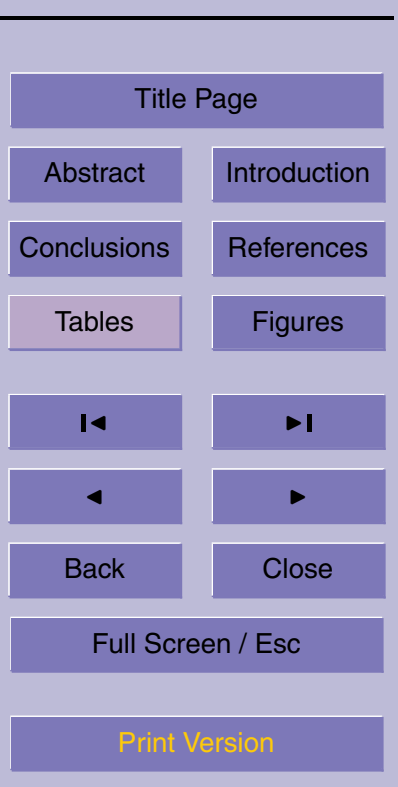

Interactive Discussion 
(a)

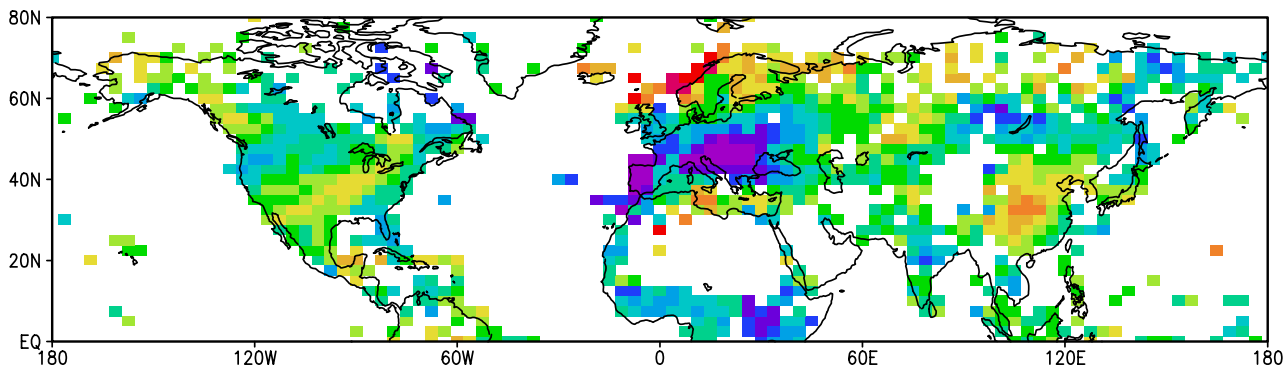

$\begin{array}{lllll}-0.5 & -0.4 & -0.3 & -0.2 & -0.1\end{array}$

0

0.1

0.2

0.3

0.6

(b)

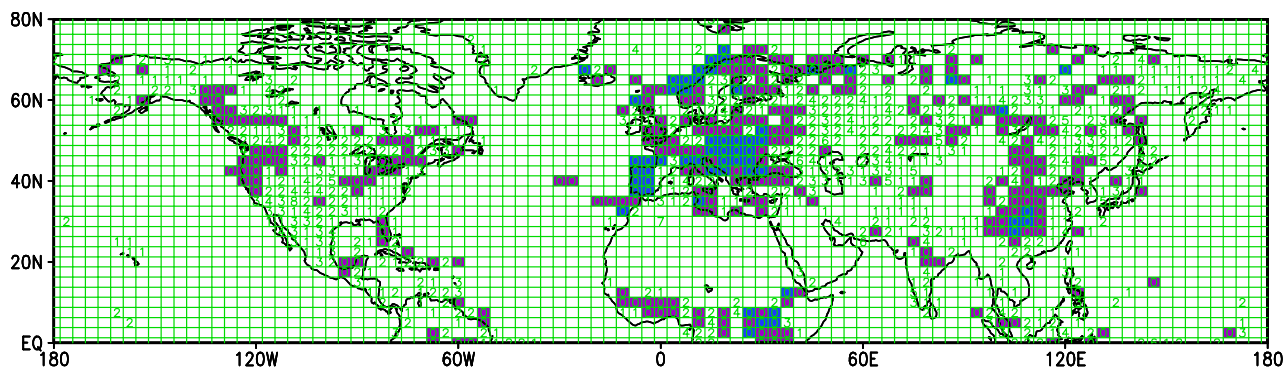

Fig. 8. As in Fig. 5, but for precipitation (boreal winter). Empty boxes represent areas with insufficient data.
$1,17-56,2005$

Optimal sites for AO reconstruction

G. Lohmann et al.

\section{Title Page}

\begin{tabular}{|c|c|}
\hline Abstract & Introduction \\
\hline Conclusions & References \\
\hline Tables & Figures \\
\hline & \\
\hline I & \\
\hline & \\
\hline Back & \\
\hline
\end{tabular}

\section{Full Screen / Esc}

Print Version

Interactive Discussion 
(a)
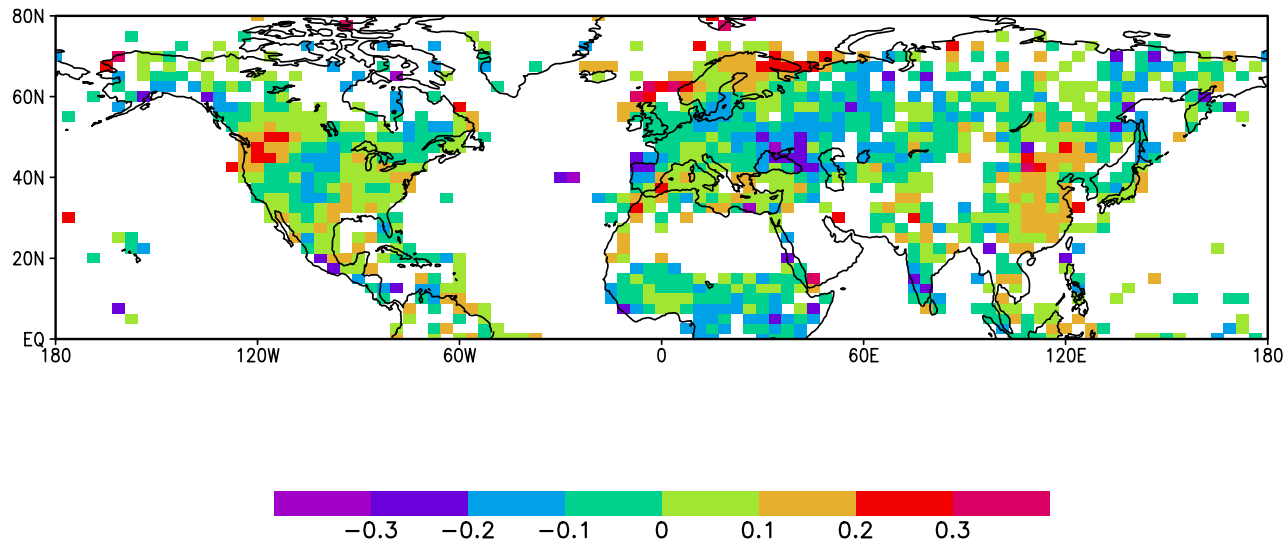

(b)

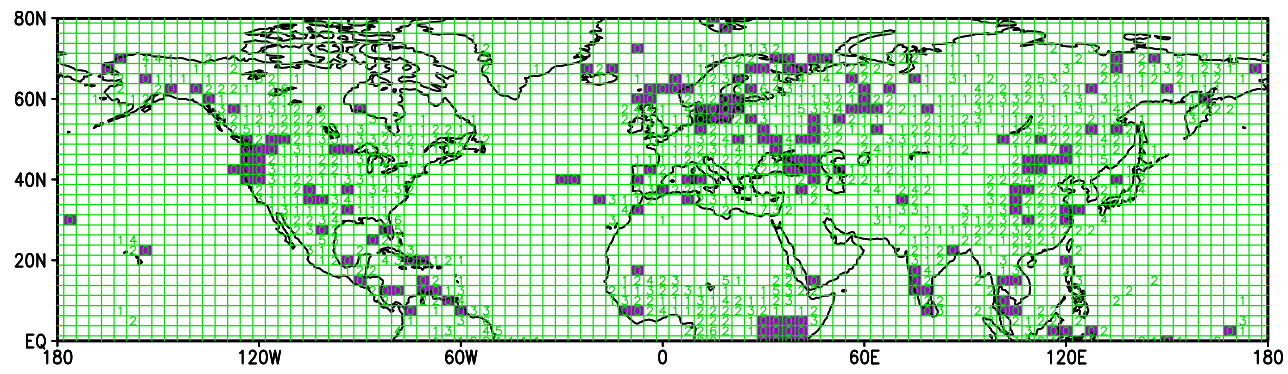

Fig. 9. As in Fig. 8, but for precipitation during boreal spring.
$1,17-56,2005$

Optimal sites for $\mathrm{AO}$ reconstruction

G. Lohmann et al.

\section{Title Page}

\begin{tabular}{|c|c|}
\hline Abstract & Introduction \\
\hline Conclusions & References \\
\hline Tables & Figures \\
\hline 14 & $\rightarrow 1$ \\
\hline 4 & $\triangleright$ \\
\hline Back & Close \\
\hline
\end{tabular}

Full Screen / Esc

Print Version

Interactive Discussion 
1, 17-56, 2005

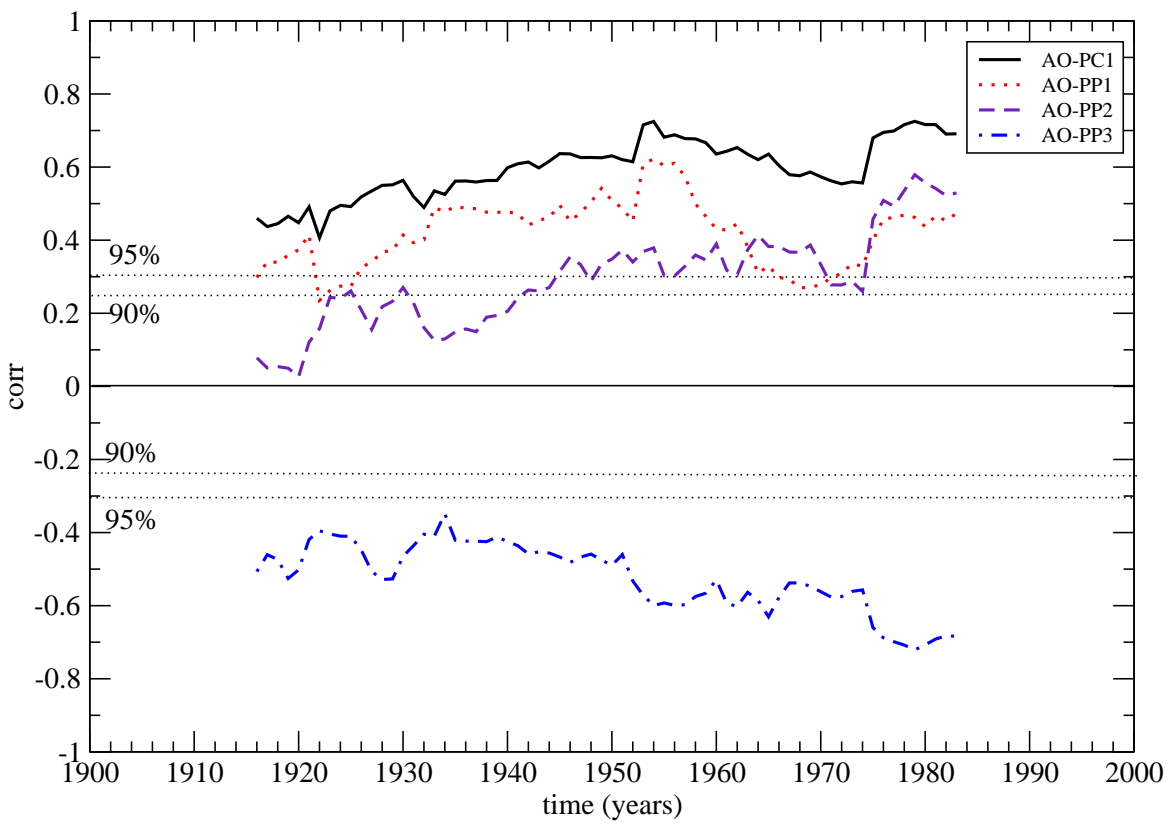

Optimal sites for AO reconstruction

G. Lohmann et al.

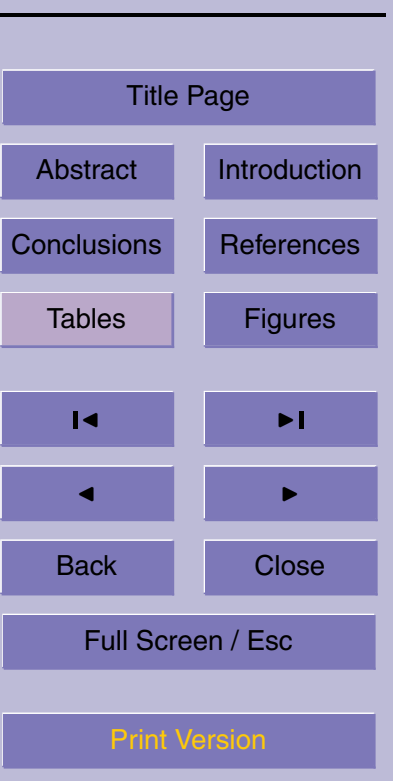

Interactive Discussion 
$1,17-56,2005$

(a)

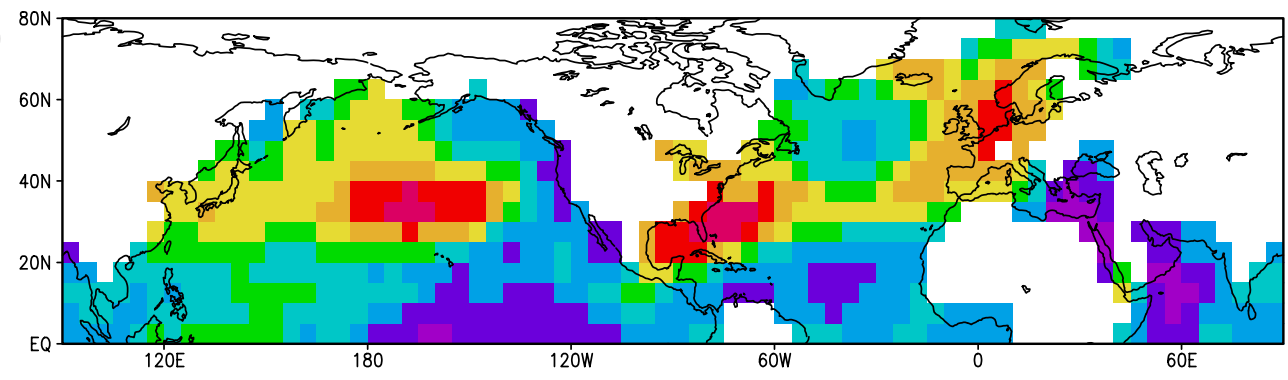

$\begin{array}{lll}-0.3 & -0.2 & -0.1\end{array}$
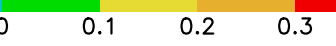

0.4

(b)

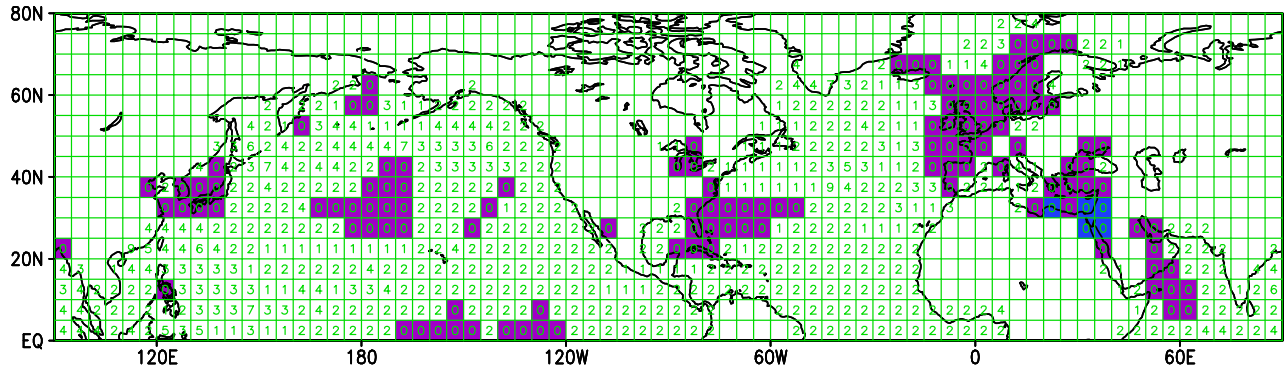

Fig. 11. (a) Correlation between the northern Red Sea coral record (Felis et al., 2000) and SST for the period 1856-1995 during boreal winter; (b) Number of shifts between the coral record and local SST anomaly time series, as in Fig. $2 \mathrm{~b}$.

\section{Optimal sites for AO reconstruction}

G. Lohmann et al.

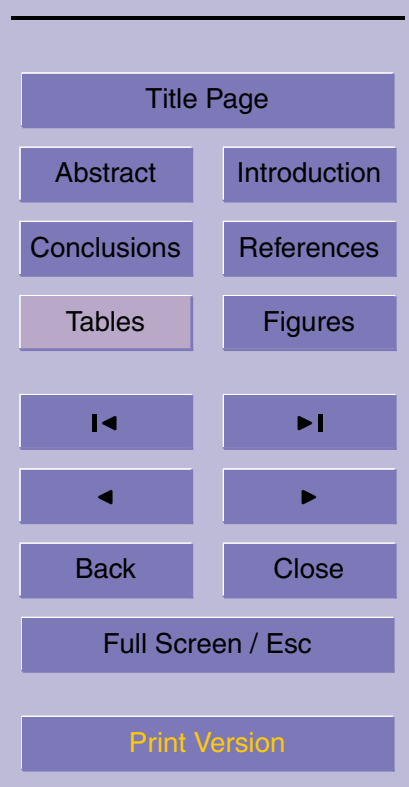

Interactive Discussion 
$1,17-56,2005$

(a)

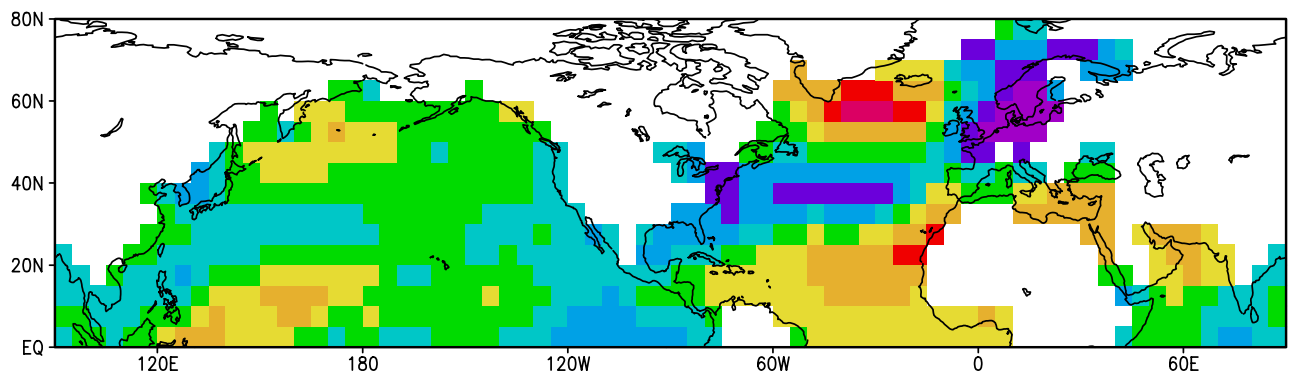

$\begin{array}{lll}-0.3 & -0.2 & -0.1\end{array}$

0

0.1

0.2

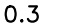

0.4

(b)

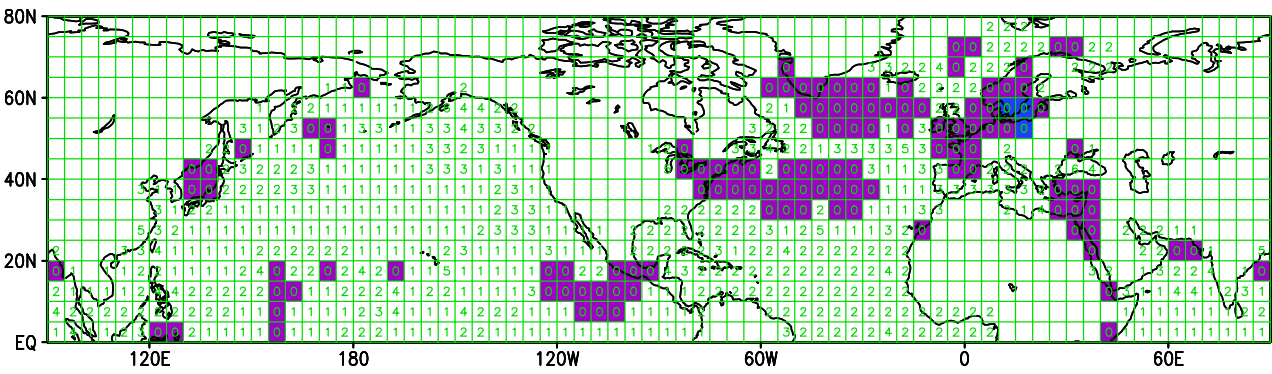

Fig. 12. As in Fig. 11, but for the time series based on seasonal resolved Greenland ice cores (Vinther et al., 2003) and for the period 1856-1970.

\section{Optimal sites for AO reconstruction}

G. Lohmann et al.

\section{Title Page}

\begin{tabular}{|c|c|}
\hline Abstract & Introduction \\
\hline Conclusions & References \\
\hline Tables & Figures \\
\hline 14 & $\rightarrow 1$ \\
\hline 4 & 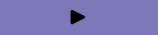 \\
\hline Back & Close \\
\hline \multicolumn{2}{|c|}{ Full Screen / Esc } \\
\hline Print & rsion \\
\hline
\end{tabular}

Interactive Discussion 
(a)

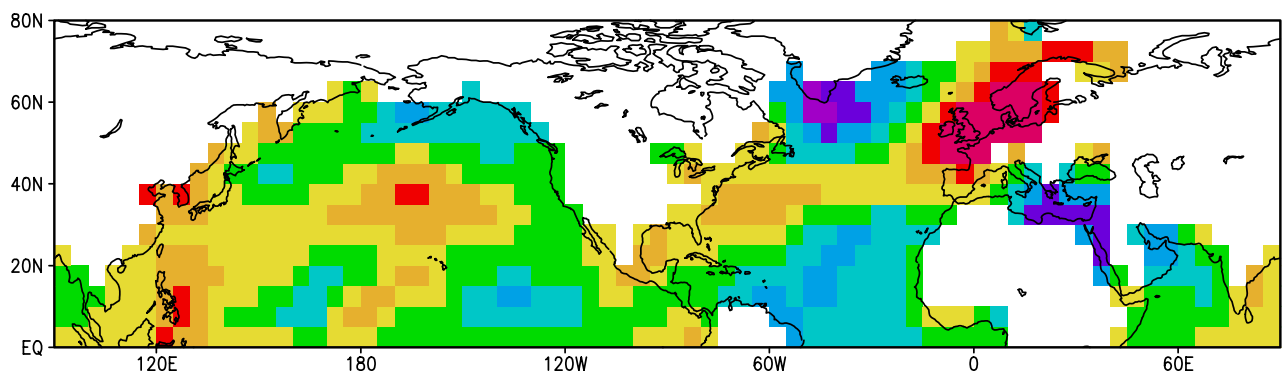

$\begin{array}{llll}-0.4 & -0.3 & -0.2 & -0.1\end{array}$

0.1

0.2

0.3

(b)

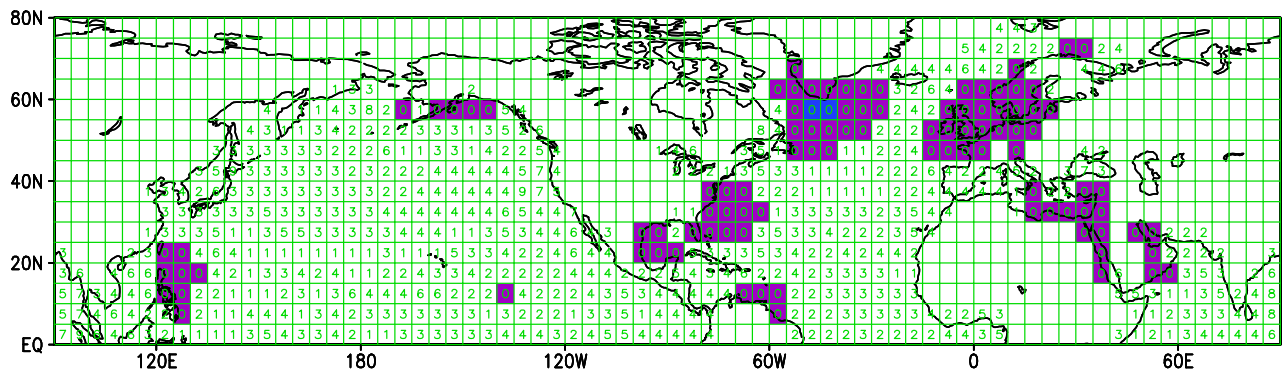

Fig. 13. As in Fig. 11, but for the time series based on mollusk shells from the central North Sea (Schöne et al., 2003) and for the period 1856-2000.
$1,17-56,2005$

\section{Optimal sites for AO} reconstruction

G. Lohmann et al.

\section{Title Page}

\begin{tabular}{|c|c|}
\hline Abstract & Introduction \\
\hline Conclusions & References \\
\hline Tables & Figures \\
\hline I & \\
\hline & \\
\hline Back & \\
\hline
\end{tabular}

\section{Full Screen / Esc}

Print Version

Interactive Discussion 
(a)

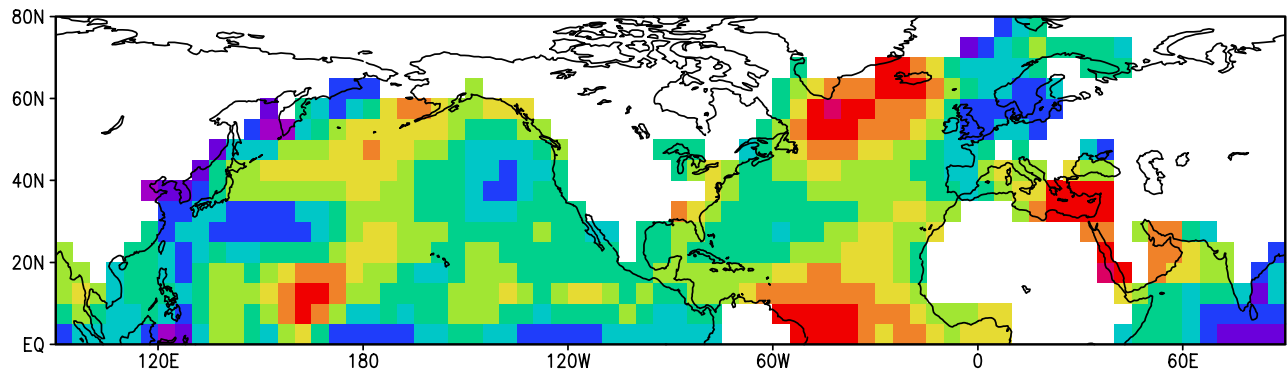

$\begin{array}{lll}-0.3 & -0.2 & -0.1\end{array}$

0.1

0.2

0.3

(b)

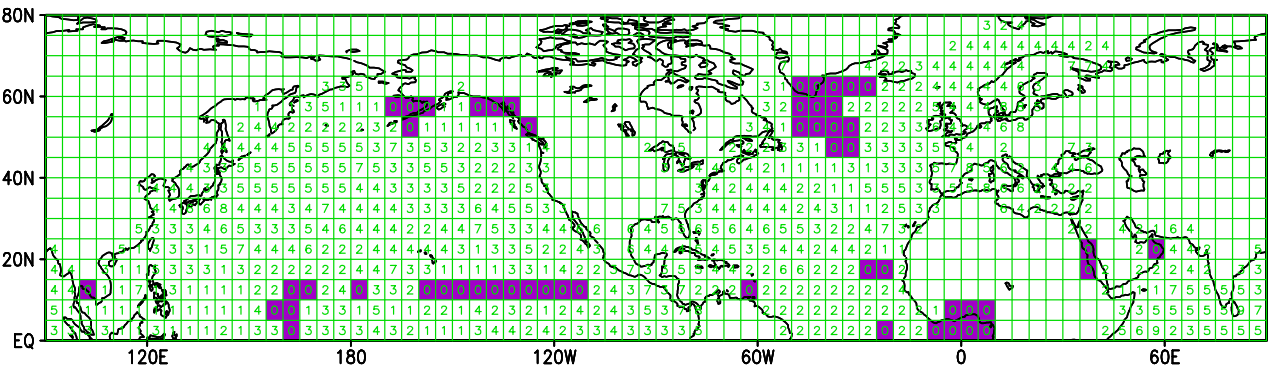

Fig. 14. As in Fig. 11, but for the time series based on stalagmite data from Scotland (Proctor et al., 2000) and for the period 1856-1995.
$1,17-56,2005$

Optimal sites for AO reconstruction

G. Lohmann et al.

\section{Title Page}

\begin{tabular}{|c|c|}
\hline Abstract & Introduction \\
\hline Conclusions & References \\
\hline Tables & Figures \\
\hline 14 & $\rightarrow 1$ \\
\hline 4 & 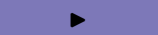 \\
\hline Back & Close \\
\hline \multicolumn{2}{|c|}{ Full Screen / Esc } \\
\hline Print & sion \\
\hline
\end{tabular}

Interactive Discussion 
(a)

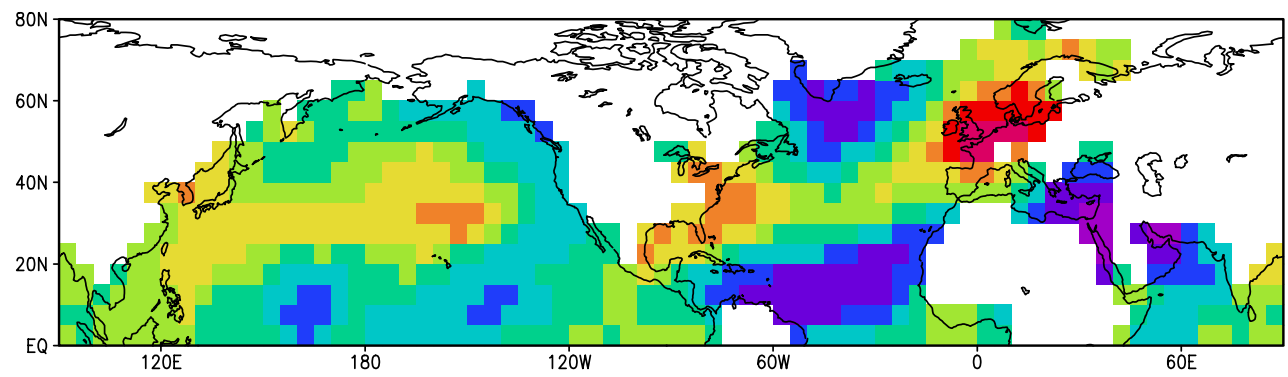

$-0.4$

$-0.3$

$-0.2$

$-0.1$

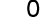

0.1

0.2

0.3

(b)

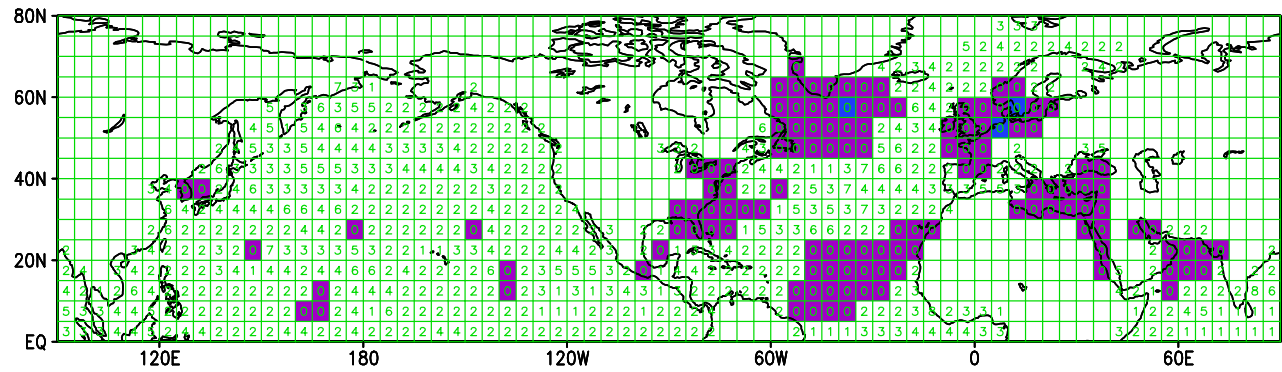

Fig. 15. As in Fig. 11, but for the NAO reconstruction based on tree rings (Cook et al., 2002) and for the period 1856-2000.
1, 17-56, 2005

Optimal sites for AO reconstruction

G. Lohmann et al.

\section{Title Page}

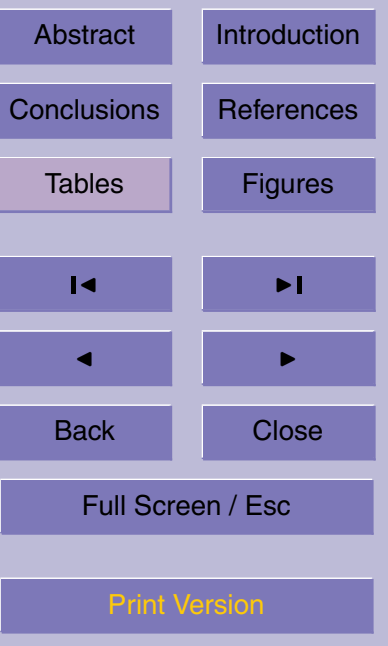

Interactive Discussion 
(a)

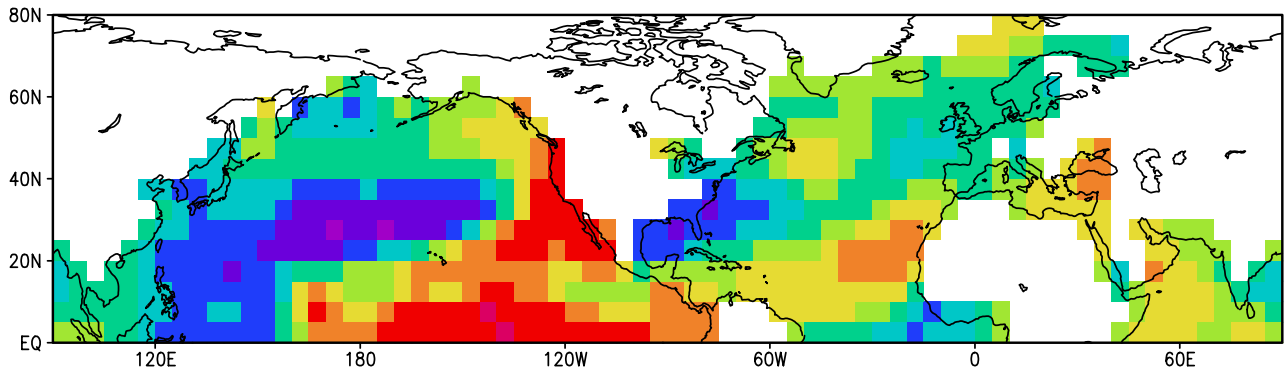

$\begin{array}{llll}-0.4 & -0.3 & -0.2 & -0.1\end{array}$

(b)

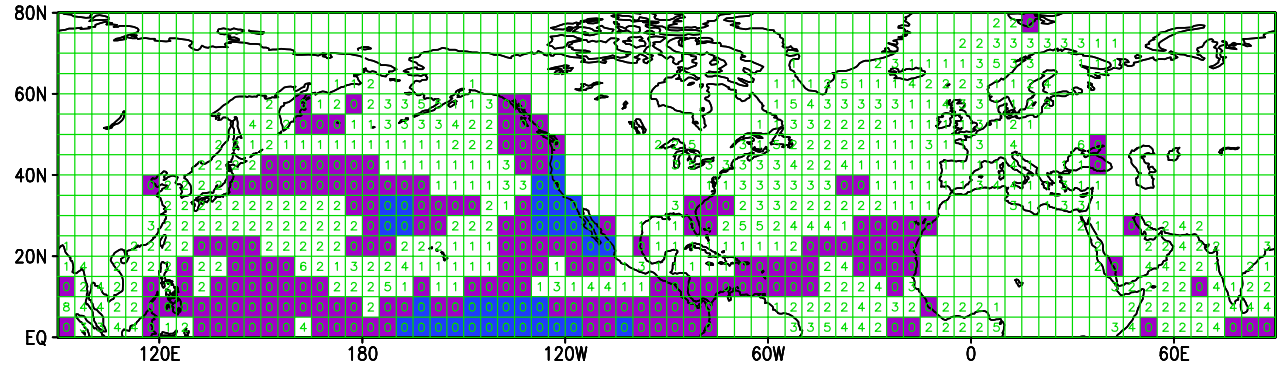

Fig. 16. As in Fig. 11, but for the tropical Pacific Ocean SST reconstruction $\left(160^{\circ} \mathrm{W}-120^{\circ} \mathrm{W}\right.$; $0^{\circ}-15^{\circ} \mathrm{N}$ ) based on coral data (Evans et al., 2000) and for the period 1856-2000.
$1,17-56,2005$

\section{Optimal sites for AO reconstruction}

G. Lohmann et al.

\section{Title Page}

\begin{tabular}{|c|c|}
\hline Abstract & Introduction \\
\hline Conclusions & References \\
\hline Tables & Figures \\
\hline 14 & $\triangle 1$ \\
\hline 4 & 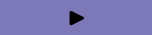 \\
\hline Back & Close \\
\hline \multicolumn{2}{|c|}{ Full Screen / Esc } \\
\hline Print & sion \\
\hline
\end{tabular}

Interactive Discussion 
(a)

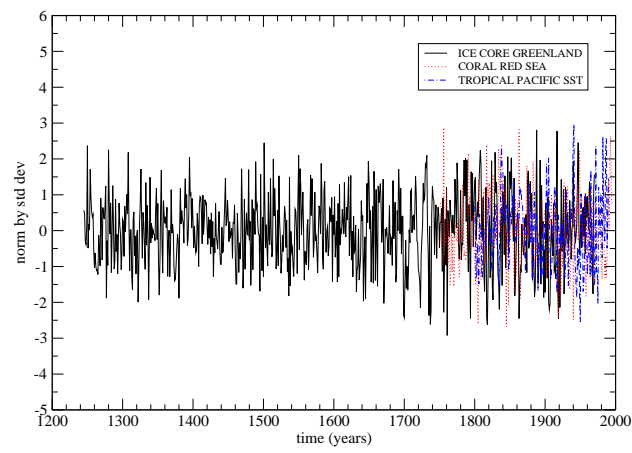

(b)

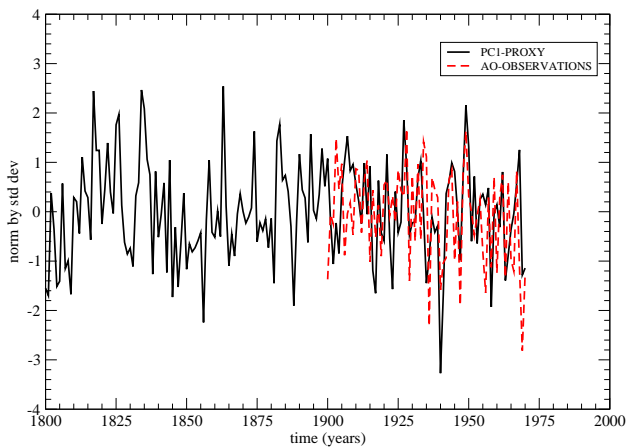

(c)

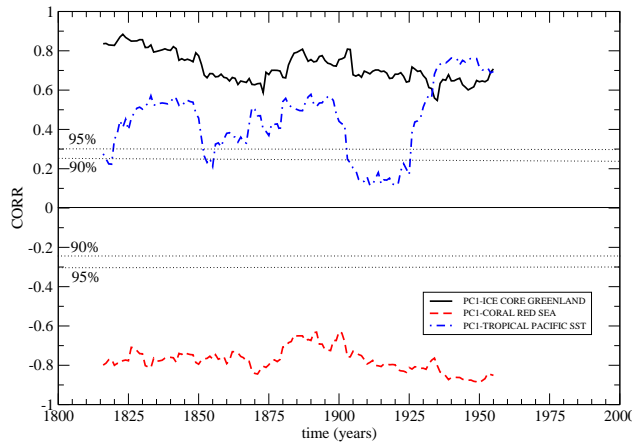

Fig. 17. (a) Normalized timeseries of Greenland ice core (Vinther et al., 2003), coral (Felis et al., 2000), and the tropical Pacific SST index derived from Evans et al. (2000). (b) PC1 of the time series in a) for the period 1800-1970. The correlation between the indices and PC1 are $-0.72,+0.77$, and -0.44 , respectively. (c) the running correlations between $\mathrm{PC} 1$ and the three time series in a). A 31-yr window has been applied in the analysis.
$1,17-56,2005$

Optimal sites for AO reconstruction

G. Lohmann et al.

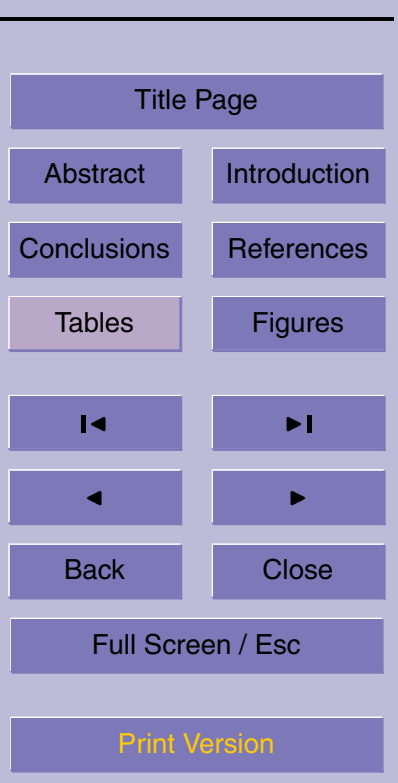

Interactive Discussion 
(a)

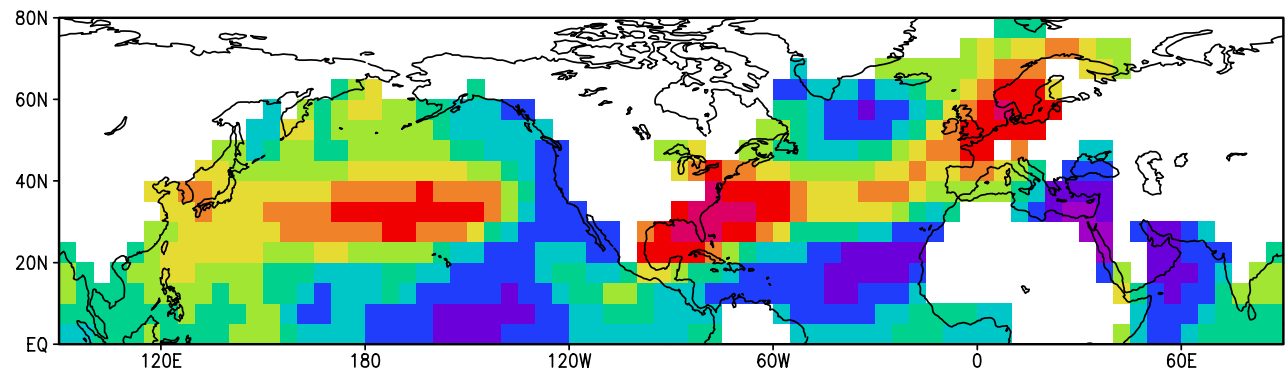

$\begin{array}{llll}-0.4 & -0.3 & -0.2 & -0.1\end{array}$

0.1

0.2

0.3

0.4

(b)

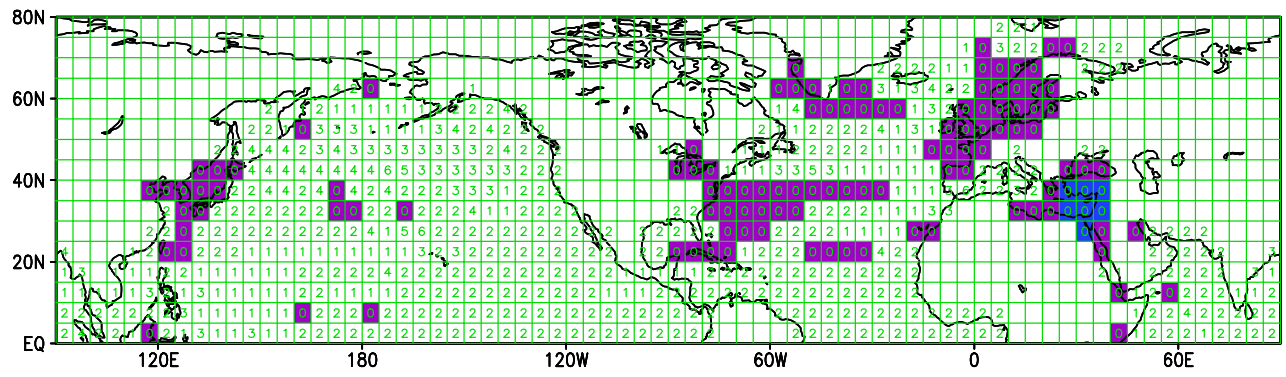

Fig. 18. As in Fig. 11, but for the PC1 shown in Fig. 17b. and for the period 1856-1970.
$1,17-56,2005$

Optimal sites for AO reconstruction

G. Lohmann et al.

\section{Title Page}

Abstract

Introduction

Conclusions

References

Tables

Figures

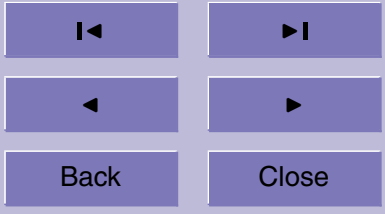

Full Screen / Esc

Print Version

Interactive Discussion 